\title{
Agrobiodiversity and its Conservation in Nepal
}

\author{
Bal Krishna Joshi ${ }^{1 @}$, Neena Amatya Gorkhali ${ }^{2}$, Neeta Pradhan ${ }^{3}$, Krishna Hari Ghimire${ }^{1}$, Tek Prasad \\ Gotame $^{4}$, Prenil KC ${ }^{5}$, Ram Prasad Mainali ${ }^{1}$, Ajaya Karkee ${ }^{1}$ and Ram Babu Paneru ${ }^{6}$ \\ ${ }^{1}$ National Agriculture Genetic Resources Center (National Genebank), NARC, Khumaltar, Nepal; @: \\ joshibalak@yahoo.com, ORCID: http://orcid.org/0000-0002-7848-5824; KHG: \\ krishnahari.ghimire@yahoo.com; RPM: mainalism.rp@gmail.com; AK: ajayakarkee@gmail.com; \\ ${ }^{2}$ Animal Breeding Division, NARC, Khumaltar; neenagorkhali@ hotmail.com \\ ${ }^{3}$ Fisheries Research Division, NARC, Godawari; pradhannita@yahoo.com \\ ${ }^{4}$ Horticulture Research Division, NARC, Khumaltar; gotame@gmail.com \\ ${ }^{5}$ Pasture and Fodder Research Division, NARC, Khumaltar; prenilkc9@gmail.com \\ ${ }^{6}$ Entomology Division, NARC, Khumaltar; rbpaneru10@gmail.com
}

Received 25 July 2019, Revised 07 Nov 2019, Accepted 15 Jan 2020, Published 17 March 2020

Scientific Editors: Madan R. Bhatta, Pashupati Chaudhari, Hari K. Upreti, Krishna Timsina

Copyright (O 2020 NARC. Permits unrestricted use, distribution and reproduction in any medium provided the original work is properly cited.

The authors declare that there is no conflict of interest.

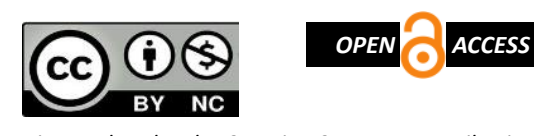

Licensed under the Creative Commons AttributionNonCommercial 4.0 International (CC BY-NC 4.0)

\section{ABSTRACT}

Nepal is a part of the world's biodiversity hotspot and ranks the $49^{\text {th }}$ in the world for biodiversity. Agrobiodiversity and its conservation status were studied through literature review, field survey, key informant survey and focus group discussion. Results of field implementation of some good practices and action research were also documented. Among 24,300 total species in the country, 28\% are agricultural genetic resources (AGRs), termed as agrobiodiversity. Agrobiodiversity has six components (crops, forages, livestock, aquatic, insects and microorganisms) and four sub-components (domesticated, semi-domesticated, wild relatives and wild edible) in Nepal. Agrobiodiversity on each component exists at agroecosystem, species, variety/breed/biotype/race/strain, genotype and allele levels, within an altitude range from 60 to 5,000 masl. There are 12 agroecosystems supporting 1026 species under crop component, 510 under forage, 35 under livestock, 250 under the aquatic animal, 17 under aquatic plant, 3,500 under insect and 800 under microorganism. An estimated loss of agrobiodiversity is $40 \%$, however, farmers have reported up to $100 \%$ loss of AGRs in some areas for a particular species. Conservation of agrobiodiversity has been initiated since 1986. Four strategies namely ex-situ, on-farm, in-situ and breeding have been adopted for conservation and sustainable utilization of AGRs. Eighty good practices including process, methods and actions for managing agrobiodiversity have been in practice and these practices come under five conservation components (sensitization, method and approach, accelerator, value and enabling environment). Within the country, 18,765 accessions of AGRs have been conserved in different kinds of banks. A total of 24,683 accessions of Nepalese crops, forages and microbes have been conserved in different international and foreign genebanks. Some collections are conserved as safety duplication and safety backup in different CGIARs' banks and World Seed Vault, Korea. Two global databases (GENESYS and EURISCO) have maintained 19,200 Nepalese accessions. Geographical Information System, Climate Analog Tool and biotechnological tools have been applied for better managing AGRs. Many stakeholders need to further concentrate on the conservation and utilization of AGRs. Global marketing of some native AGRs is necessary for sustaining agriculture and attracting young generations as well as conserving them through use.

Keywords: Agrobiodiversity, aquatic resource, conservation, crop, forage, good practices, insect, livestock, microorganism 
सारांश

नेपाल विश्व जैविक विविधताको हिसाबले ४९ औँ स्थानमा आउँछ। विविध सन्दर्भ सामग्री अध्ययन, फिल्ड सर्वेक्षण, मुख्य सूचनादाता सर्वेक्षण, केन्द्रित समुह छलफल, असल अभ्यास अवलम्बन र कार्यमूलक अनुसन्धान मार्फत् नेपालमा कृषि जैविक विविधता र यसको संरक्षणको अवस्थाबारे अध्ययन गरिएको थियो। देशमा भएका कुल २४,३०० जीवित प्रजातिहरू मध्ये २८\% कृषि आनुवंशिक स्रोतहरु छन्, जसलाई कृषि जैविक विविधता भनिन्छ। कृषि जैविक विविधताका बाली, घाँसे बाली, पशुपन्छी, जलचर, कीरा र सुक्ष्म जीवाणु गरी ६ वटा सम्भागहरु तथा खेती गरिने/घरपालुवा, अर्ध-जंगली, जंगली नातेदार र जंगली खान योग्य गरी ४ वटा उप-सम्भागहरु छन्। समुन्द्र सतहबाट ६० मिटरदेखि ५००० मिटरको उचाईसम्म पाइने कृषि जैविक विविधताका प्रत्येक सम्भागमा बिभिन्न तह (पारिस्थिकीय प्रणाली, प्रजाति, जात तथा आनुवंशिक) मा विविधता पाइन्छ। नेपालभर १२ कृषि पारिस्थिकीय प्रणालीमा करिब १०२६ प्रजातिका बालीहरु, ५९० प्रजातिका घाँसेबालीहरु, ३५ प्रजातिका पशुपन्छीहरु, २५० प्रजातिका जलचर प्राणीहरु, १७ प्रजातिका जलचर वनस्पतिहरु, ३५०० प्रजातिका लाभदायक कीराहरू तथा ८०० प्रजातिका लाभदायक सुक्ष्म जीवाणुहरु भएको अनुमान छ। बिभिन्न क्षेत्रहरुमा गरी औसतमा करीब ४०\% कृषि जैविक विविधता ह्रास भएको छ, तर पनि कतिपय क्षेत्र र प्रजातिमा शत प्रतिशतसम्म कृषि जैविक विविधता ह्रास भएको रिपोर्ट छ। नेपालमा कृषि जैविक विविधता संरक्षणको काम २०४३ साल बाट शुरु भएको पाइन्छ। कृषि आनुवंशिक स्रोतहरुको संरक्षण तथा दिगो उपयोगको लागि पर-स्थान, खेती-स्थल, यथा-स्थान तथा प्रजनन् गरी $४$ किसिमका रणनीतिहरु अवलम्बन गरिएका छन् । कृषि जैविक विविधताको व्यवस्थापनको लागि ५ वटा संरक्षण सम्भाग (जागरण, तौर तरिका, उत्प्रेरणा बृद्धि, मुल्य-मान्यतायुक्त वातावरण) अन्तर्गत ८० वटा असल अभ्यासहरु प्रयोजनमा आएका छन् । देशभित्रका बिभिन्न बैंकहरुमा १८,७६५ वटा कृषि आनुवंशिक स्रोतहरु संरक्षित छन् भने बिदेशका बिभिन्न अन्तरराष्ट्रीय बैंकहरुमा नेपालका बाली, घाँसेबाली, कीरा तथा सुक्ष्म जीवाणुहरुका २४,६८३ वटा संकलनहरु रहेका छन् । यी मध्ये केही संकलनहरु सुरक्षित प्रतिरुप भण्डारणको रुपमा संरक्षित छन् भने दुईवटा विश्वव्यापी डाटाबेसमा १९,२०० वटा नेपाली संकलनहरु रहेका छन् । कृषि आनुवंशिक स्रोतको समुचित व्यवस्थापनको निम्ति भौगोलिक सूचना प्रणाली (GIS), सम-जलवायु टुल सफ्टवेयर (CAT) र जैविक प्रविधिको प्रयोग गरिएको छ। कृषि आनुवंशिक स्रोतको संरक्षण र उपयोगमा सबै सरोकारवालाहरुको ध्यान जानु आवश्यक छ। कृषिमा दिगोपना ल्याउन, युवा आकर्षण बढाउन तथा कृषि आनुवंशिक स्रोतको संरक्षण र उपयोगको निम्ति नेपालका केही बिशेष आनुवंशिक स्रोतहरुलाई विश्व बजारमा पुर्याउनु अति जरुरी हुन्छ।

\section{INTRODUCTION}

Total estimated species of living being on earth is 8.7 million, of which 1.3 million have been identified (Sweetlove 2011, Zimmer 2011). Nepal is part of world's biodiversity hotspot (https://www.cbd.int/countries/profile/?country=np). She ranks the $49^{\text {th }}$ position in the world on biodiversity with $0.17 \mathrm{BioD}$ index, the $31^{\text {st }}$ and the $10^{\text {th }}$ in flowering plant diversity in the world and

Asia respectively. Brazil is the first country with 0.85 BioD index (https://news.mongabay.com/2016/05/top-10-biodiverse-countries/). On the basis of per unit area, Nepal ranks the $27^{\text {th }}$ position with 1.16 BioD index per land area and Brunei comes $1^{\text {st }}$ with 18.68 BioD index per land area. The country occupies $0.03 \%$ of the global area but harbors over $3 \%$ and $1 \%$ of the world's known flora and fauna, respectively. There are 118 types of ecosystems with 75 vegetation types, 35 forest types and 5 rangeland ecosystems (MoFSC 2014).

Nepal is a mountainous agricultural country where $65 \%$ populations are involved in agriculture, with only $21 \%(3,091,000$ ha) cultivated land. A large number of landraces exist in the country, but up to now, only 37 local landraces of 19 crops have been utilized in breeding to develop 41 crop varieties (Joshi 2017a). In 2019 only, Nepal has imported 5,741 genotypes (accessions) of 31 crops for breeding and shared 221 accessions of wheat to the CGIAR system (Hari B. KC 2019, Personal Comm.). Crop cultivation ranges from $60 \mathrm{~m}$ (in Kechana Kalan, Jhapa, where rice is grown) to 4,700 $\mathrm{m}$ (in Khumbu, Solukhumbu, where potato is grown) altitude (Joshi et al 2017a). However, just three crops, rice, wheat and maize cover $83 \%$ of the total cultivated land of the country (Joshi et al 2019), indicating vulnerable to loss of crop diversity and climate change.

Agrobiodiversity is the most important subset of biodiversity. It is further divided into six components (crops, forages, livestock, aquatic, insects and microorganisms) and four sub-components (domesticated, semi-domesticated, wild relatives and wild edible) in Nepal. Crop component includes agronomic (cereals, pseudo-cereals, millets, pulses, oilseeds, sugar and starch, and fiber), horticultural (vegetable, spices, beverage, fruit, ornamental and domesticated medicinal) crops. Forage species cover grasses, trees and shrubs growing either in farming land or forest areas. Wild edible forages mean wild forage species, edible to livestock. Livestock includes wild and farm animals, birds that have direct values. Aquatic component covers agricultural animals and plants found in aquatic areas. Insect and microbe components cover only beneficial and economic species. Insect genetic resources 
are moths, butterflies, and other insects, and also included spiders and worms, whereas microbial genetic resources include fungi, lichens, algae, bacteria and others. Beneficial insects and microorganisms mean those that have an indirect positive value, and economic organisms are those that have direct value to human mankind. Wild edible insect and microorganism cover both beneficial and food values organisms.

Conservation has got priority after the CBD 1992 in the world. Total genebank in the world is now 1,750 conserving 7.5 million accessions, most of which are orthodox crops and forages (FAO 2010). Altogether 5,515,066 accessions of different crop and forage species are available through the multilateral system (MLS) of the International Treaty on Plant Genetic Resources for Food and Agriculture (ITPGRFA) (https://mls.planttreaty.org/itt/index.php?r=stats/pubStats). In Nepal, protected areas and National Genebank are the major milestones for the conservation of biodiversity and agrobiodiversity respectively. Twenty protected areas in Nepal cover $23 \%\left(34,193 \mathrm{~km}^{2}\right)$ areas of the country (MoFSC 2014). Diversity in crop component is also supported by informal and non-formal seed supply systems, which accounts for about 85 to $100 \%$ in Nepal depending on crop species. Enabling the environment has been created through becoming members of different international agreements and developing national legal documents. Nepal became a member of the Convention on Biological Diversity (CBD) in 1992 and of ITPGRFA in 2009. Nepal is also a party of The Cartagena Protocol on Bio-safety-2000 since 2001, of Nagoya Protocol-2014 since 2019 and have Agrobiodiversity Policy (2007) revised 2014, Seed Act 1988 (Amend 2008), National Seed Vision 2013-25, National Seed Policy 1999, NBSAP 2014-2020, IPR Policy 2017 and IMISAP 2018-2025 for conservation of biodiversity including agrobiodiversity.

This paper has analyzed the status and initiatives for the management of agrobiodiversity in Nepal, with the objective of making conservation options, process, methods and good practices available, to develop the baseline and to make common understanding on agrobiodiversity and conservation.

\section{METHODOLOGY}

This paper is based on literature review, field survey, key informant survey (KIS) and focus group discussion. Results of field implementation of some good practices, processes, methods and action research were compiled. Agrobiodiversity conservation has been initiated since 1986 in Nepal. A number of publications are available since then. This study reviewed those publications along with relevant websites and electronic literature. Information was collected by visiting more than 50 different kinds of fields, eg farmer fields, protected areas, research stations, farming communities, etc. KIS was conducted with more than 50 experts, 25 focus group discussions (FGDs) were held and 100 farmers were consulted for information collection and validations. Interviews were either face to face interaction, email or telephone conversations. NAGRC, LI-BIRD, MoALD and Bioversity International have jointly implemented more than 25 agrobiodiversity conservation $(A B C)$ projects across the country since 1997. Different methods and approaches have been adopted and these activities were directly implemented in the fields; labs and research stations. Outputs of these activities implemented in these sites were analyzed and summarized. A checklist on different perspectives of agrobiodiversity was used to collect information from 2015 to 2019. Species were grouped under different agrobiodiversity components considering their principal use.

\section{RESULTS AND DISCUSSION}

\section{Agrobiodiversity in Nepal}

A total of 24,300 biological species are reported in Nepal (Figure 1). Among them, 28\% (ie 6,618 species) are agricultural species excluding 27 exotic ornamental fish species. The species richness of agricultural fauna $(3,785$ species $)$ is higher than agricultural flora $(2,833$ species $)$. The number of agricultural species is the highest in insect component $(3,500)$, followed by crop component $(1,026$ species) and microorganism component (800 species). Species richness of livestock component is the least among six components of agrobiodiversity. The numbers of each component and sub-component of agrobiodiversity are given in Table 1 along with the estimated loss percentage. The number of wild edible species is higher in all components except forage and livestock components. Due to the high 
level of eco-geographic and climatic variation in Nepal, a total of 1,506 species of agricultural crop and forage genetic resources have been reported (Upadhyay and Joshi 2003, MoAD 2017, Joshi et al 2017). Out of these, 93 introduced species, 670 wild edible plants, 224 crop wild relatives, 35 semidomesticated and 484 cultivated native species exist. Among 484 native cultivated species, 64 are agronomic, 145 are horticultural and 275 are forages species.

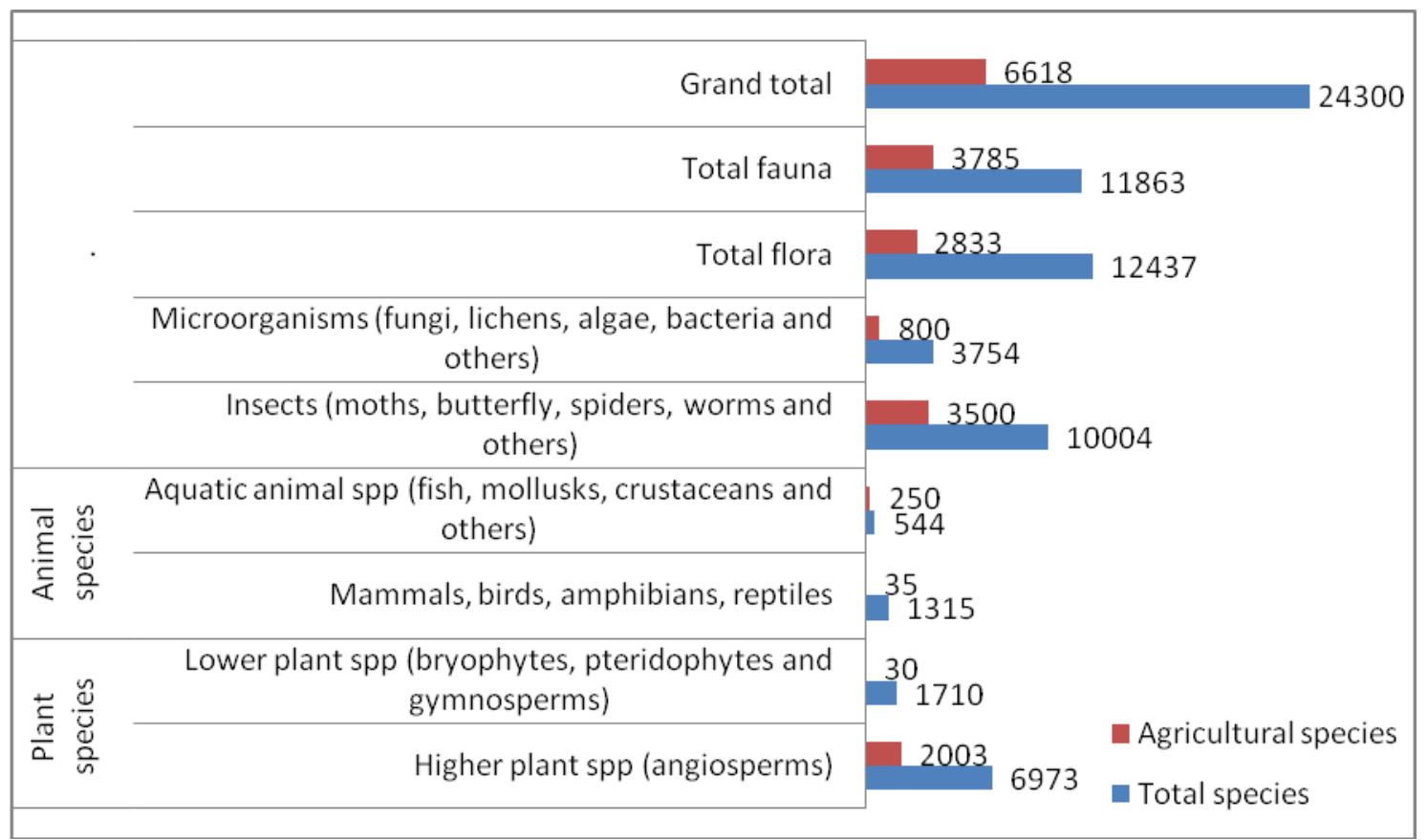

Figure 1. Total number of species and agricultural species in Nepal (27 exotic ornamental fish species available in Nepal are not included in the figure. Among 2003 higher plant species, there are 17 aquatic agricultural plant species, 300 ornamental species, 180 medicinal and 510 forage species. Altogether 232 fin fish species have been reported). Source: Wilson 1997, Thapa 1997, Shrestha 1999, Upadhyay and Joshi 2003, Sharma 2007, van Huis et al 2013, MoFSC 2014, Raut 2014, Joshi et al 2016b, Joshi et al 2016c, Joshi et al 2017, Gurung 2017, Joshi et al 2019, Husen 2019

Cultivated ornamental plant species include 100 exotic and 200 natives (Anil Acharya, Personal Comm. 2019). Among 700 medicinal plant species, 120 native species are under cultivation and 60 species are exotic (Sharma 2007). Existing crop genotypes are landraces, modern, released, registered, de-notified, hybrid, inbred, open pollinated variety (OPV), exotic, native, bulk, mixture, partial hybrid, breeding line, mutant, organ transplant organism (OTO), multiline, near isogenic line (NIL), double haploid (DH), synthetic, clonal, and genetically modified organism (GMO). However, in other agrobiodiversity components, there is very low intra-specific diversity (different genotypes). Forage species and rangeland are found from $60 \mathrm{~m}$ to $5000 \mathrm{~m}$ (Abington 1992). There are total of 510 forage species including 50 exotic.

Table 1. Number of species and estimated loss percentage (in parenthesis) of agricultural genetic resources in Nepal

\begin{tabular}{|c|c|c|c|c|c|}
\hline \multirow{2}{*}{$\begin{array}{l}\text { Agrobiodiversity } \\
\text { Component }\end{array}$} & \multicolumn{4}{|c|}{ Subcomponent } & \multirow{2}{*}{$\begin{array}{l}\text { Total } \\
\text { (Average) }\end{array}$} \\
\hline & $\begin{array}{l}\text { A. Domesticated } \\
\text { [exotic] }\end{array}$ & $\begin{array}{l}\text { B. Semi } \\
\text { domesticated }\end{array}$ & $\begin{array}{l}\text { C. Wild } \\
\text { relatives }\end{array}$ & $\begin{array}{l}\text { D. Wild } \\
\text { edible }\end{array}$ & \\
\hline 1. Crop genetic resources & 252 [ex.43] (60) & $30(45)$ & $214(45)$ & $500(50)$ & $996(50)$ \\
\hline 2. Forage genetic resources & $325[$ ex.50] (40) & $5(35)$ & $10(40)$ & $170(45)$ & $510(40)$ \\
\hline $\begin{array}{l}\text { 3. Livestock genetic } \\
\text { resources }\end{array}$ & 17 [ex.4] (45) & $3(35)$ & $4(30)$ & $11(50)$ & $35(40)$ \\
\hline $\begin{array}{l}\text { 4. Aquatic genetic } \\
\text { resources (animal+plant) }\end{array}$ & $\begin{array}{c}28 \text { [ex.16] }(40)+ \\
2 \text { [ex.0] (40) }\end{array}$ & $\begin{array}{c}5(30)+2 \\
(30)\end{array}$ & NK & $\begin{array}{l}217(35)+ \\
13(35)\end{array}$ & $\begin{array}{l}250(30)+ \\
17(35)\end{array}$ \\
\hline 5. Insect genetic resources & $18[$ ex.11] (15) & $5(10)$ & $10(10)$ & $3467 *(45)$ & $3500(20)$ \\
\hline $\begin{array}{l}\text { 6. Microbial genetic } \\
\text { resources }\end{array}$ & $24[\mathrm{ex} .8](15)$ & $10(10)$ & $6(20)$ & $760 *(35)$ & $800(20)$ \\
\hline Total & 658 [ex.124] (36) & $60(28)$ & $244(30)$ & $5146(45)$ & $6108(35)$ \\
\hline
\end{tabular}


NK, Not known. Domesticated species includes both native and exotic species. Numbers of exotic [ex.] species are in square bracket. For insect genetic resources domesticated species also include species that are used for humankind by artificial mass rearing for managing insect pests or weeds as a means of biological control. Ornamental (300), medicinal (180) and lower agricultural plant (30) species are not included in this table. * This is an estimated value based on survey and literature. Source: Regmi 1982, Banwart 1989, Paudel and Tiwari 1992, Upadhyay et al 1995, Smith et al 1996, Thapa 1997, Wilson 1997, Shrestha and Shrestha 1999, Shrestha 1999, Yami et al 2003, Upadhyay and Joshi 2003, Arjyal et al 2004, MoAC 2004, Takeda et al 2004, Sharma 2007, Christensen et al 2008, Niroula and Sing 2011, Acharya and Atreaya 2012, van Huis et al 2013, MoFSC 2014, Raut 2014, Gotame et al 2014, Aryal et al 2015, Bhattarai et al 2015, Shimada and Basnet 2015, Paudel 2017, Subba et al 2017, Joshi et al 2017, Gurung 2017, Wilson 2017, Joshi et al 2019, Husen 2019, Limbu et al 2019, FAO 2019, Suresh Wagle, Personal Comm. 2019, Ajaya Chaudhary, Personal Comm. 2019

Livestock is reared at an altitude range of $60 \mathrm{~m}$ to 5,000 $\mathrm{m}$ (Abington 1992). Among the 35 agricultural animal species, 17 are domesticated which consist of 13 native and four exotic livestock species. Four semi-domesticated animals are Dhorel sheep, wild yak, pigeon (rock dove, parewa) and quail bird (battaai charaa). Four wild relatives of livestock species are wild boar (Badel), Arna (buffalo), red jungle fowl (chicken) and gaur. There are about 11 wild edible animal species (though they are not killed for this purpose from the forest). They are Kaalij Pheasant, Wild Rabbit (Hispid hare), Mountain goat (Jharaal), Deer (harin), Himalayan Thar (Wild Goat, Hemitragus tahr), Bharal or blue sheep, Mountain quail or partridge (Titraa), Dove (Dhukur), Bat (chamero), Dumsi and Swan (raajhaas). Three common pet animals are dog, cat and parrot.

Aquatic agricultural genetic resources (aquatic agrobiodiversity) include aquatic plants and animal species. There are 17 aquatic agricultural plant species and 250 aquatic agricultural animal species (MoFSC 2014, Gurung 2017, Joshi et al 2019, Ajaya Chaudhary, Personal Comm. 2019). Fish species are reported from wide range of altitudes (ie 60 to $4000 \mathrm{~m}$ ) (Shrestha 1999, http://www.fao.org/3/x2614e/x2614e03.htm). Among the total 232 fin fish, 16 are exotic and 216 indigenous including 15 ornamental fish species (Gurung 2017, Husen 2019). All fish species are edible and 28 species (16 exotic and 12 native) are under cultivation. Fish species richness is assessed from many areas but diversity below species levels, mainly at strain level has not been studied.

Insect genetic resources include beneficial insects that have been used in biological control, pollination or industrial purposes such as predators and parasitoids, and economic insect eg honeybees, stingless bees and lac insects. The number of native insect species is 10004, of which 3500 are estimated as beneficial and economic insect species (Thapa 1997, MoFSC 2014). About 18 species are domesticated including eleven exotic species. Here domestication represents at least mass rearing of an insect for humankind. Exotic species are either imported by a government body (7 species) or unintentionally arrived in Nepal after their successful release in India (4 species). The widely domesticated indigenous insect species is Asian honeybee (Apis cerana), however European honeybee (A. mellifera) is widely domesticated exotic species. Other exotic species include five parasitoids, one predator, one species of silk moth, and four insect species for biological control of the weed. Most of the insect species are imported from a different origin other than Nepal as a means of classical biological control insect pests or weeds. Insect diversity at species level has been studied. However, diversity at strain and genotype levels needs to be assessed.

Among the 3,754 microbial species, 800 are reported to be beneficial and economic species. There are very limited studies on the diversity of microorganisms at species and strain levels. Twenty four species including 16 mushroom species are under cultivation. Eight cultivated microbial species are reported to be exotic. Diversity richness has been assessed in mushroom species. There are 136 wild edible mushrooms, 73 medicinal mushroom and 11 mushroom species are found both in wild and domestic land (Raut 2014, HC Bastola, Personal comm. 2019). Nepal is also a suitable living place for many beneficial micro-organisms that can kill insect pests by causing diseases on them called insect pathogens. Native Nucleopolyhedrosis viruses, granulosis viruses, green muscardine fungus, Paecilomyces fungus, white muscardine fungus, entomopathogenic nematodes including Steinernema and Heterorhabditis and Bt have been reported from Nepal (Joshi 2016). 
Diversity on crop genetic resources is higher at all five levels (agroecosystem, species, variety, genotype and allele) (Table 2). There are 12 agroecosystems, namely upland mountain agriculture, irrigated mountain agriculture, upland temperate agriculture, irrigated temperate agriculture, upland tropical agriculture, irrigated tropical agriculture, mountain wetland, temperate wetland, tropical wetland, mountain rangeland, temperate rangeland and tropical rangeland (Joshi et al 2017). All components are relatively high in species richness, however, there is low diversity at varietal/breed/strain/biotype/race, genotype and allele levels in all components except crop genetic resources. This might be because of a lack of sufficient data or research on these components.

Table 2. Relative diversity assessment on each component over five levels of agrobiodiversity

\begin{tabular}{llllllr}
\hline Agrobiodiversity Component & $\begin{array}{l}\text { Agroecosystem } \\
\text { diversity }\end{array}$ & $\begin{array}{l}\text { Species } \\
\text { diversity }\end{array}$ & $\begin{array}{l}\text { Variety/breed/ } \\
\text { race/strain/ } \\
\text { biotype diversity }\end{array}$ & $\begin{array}{l}\text { Genotype } \\
\text { diversity }\end{array}$ & $\begin{array}{r}\text { Allele } \\
\text { diversity }\end{array}$ \\
\hline 1. & Crop genetic resources & High & High & High & High & High \\
\hline 2. & Forage genetic resources & High & High & Low & Low & Low \\
\hline 3. & Livestock genetic resources & Medium & Medium & Medium & Low & Low \\
\hline 4. & Aquatic genetic resources & High & High & Low & Low & Low \\
\hline 5. & Insect genetic resources & High & High & Low & Low & Low \\
\hline 6. & Microbial genetic resources & Medium & Medium & Low & Low & Low \\
\hline
\end{tabular}

There are many site specific landraces of crops, forages, livestock, aquatic animal and plant, insect and microorganisms (Regmi 1982, Paudel and Tiwari 1992, Upadhyay et al 1995, Smith et al 1996, Wilson 1997, Yami et al 2003, Christensen et al 2008, Niroula and Sing 2011, Gotame et al 2014, Aryal et al 2015, Wilson 2017, Subba et al 2017, Joshi et al 2017b, Joshi et al 2018, Limbu et al 2019). But there is very limited information on diversity below species levels in all components of agrobiodiversity. In some extent, diversity below the species level is measured on crops and livestock components. Some of them are listed in Annex I. They are potential for getting geographical indication right, however, many of them are endangered and demand immediate attention for conservation and improvement.

\section{Genetic Erosion and its Drivers}

Estimated losses of each agrobiodiversity component are given in Table 1. On average, $40 \%$ of AGRs are lost in the country. The highest degree of loss is reported on crop genetic resources and the least on insect and microorganism diversity. Farmers in some areas have reported a loss of native AGRs up to $100 \%$. FAO (1999) had reported a loss of more than $75 \%$ of global crop diversity over the $20^{\text {th }}$ century. Many landraces are becoming rare and endangered (Upadhyay and Joshi 2003, Chaudhary et al 2004). The main reasons for genetic erosion are replacement by modern varieties, very limited use of local landraces in breeding, non-profit agricultural business, etc. Other drivers of change of agrobiodiversity are wide distribution of modern variety, natural and human-made disasters, epidemics of diseases and insect pests, changes in land use pattern and leaving land fallow or habitat loss, changes in occupation, war or insurgency, very old trees/orchards of which progeny has not been generated, rapid commercialization of agriculture; mono-genotyping, migration of farmers and land abandonment and over-exploitation eg loss of species caused by over-grazing or by uncontrolled harvesting of the wild genetic resources. There is a global debate on the decline of insect species over time (Møller 2019, Seibold et al 2019). The indiscriminate uses of pesticides are reported as the major cause. However, there is a lack of data at a global level too.

\section{Conservation}

The first collection and evaluation of indigenous plant materials were started in 1940 (Genebank 2016). Medium term seed house was established in 1986 and the first community seed bank was constructed in 1994 (Joshi 2017). The red listing system was developed in 2003 to prioritize the landraces for conservation (Joshi et al 2004). Since 2010, National Genebank with modern facilities has started working on the conservation of AGRs at a wider scale. Agrobiodiversity, though most important for food and nutrition security, relatively got less attention for conservation in comparison with forest genetic resources. Within AGRs, conservation is more focused on orthodox crop species 
(Joshi 2017, Ghimire and Joshi 2019). This may be due to the availability of easy technology to conserve such crop species. Conservation good practices including process, methods and actions, and working strategies are given below.

\section{Banking Principles}

The main principle is facilitated access to all agricultural genetic resources through long term secured conservation and making maximum interaction with biotic and abiotic stresses with germplasm to accelerate the evolutionary process. Germplasm are being managed with the facility of tracing back and forward of any accession. Germplasm is for all at free of cost and forever. Anyone can deposit collections safely for a long period of time. The black box system of storage has been created for researchers and farmers to store their materials for future use. All kinds of AGRs are banked and have been accelerated for utilization through maintaining an electronic database. A common understanding is to collect, conserve and maintain as much diversity as possible in a minimum sample. The working principle is that each diversity has a value and considers diversity at agroecosystem, species, variety/breed/strain/biotype/race, genotype and allele levels.

\section{Conservation Components and Grood Practices}

Conservation needs varied actions and multidisciplinary approaches. Conservation actions in Nepal can broadly be grouped into five components (Figure 2). Within each component, there are a number of good practices, process, methods and actions that support conservation and sustainable use of agrobiodiversity. First action is sensitization and understanding agrobiodiversity at all levels to all people. After understanding of agrobiodiversity, different methods and approaches can easily be implemented. Method and approach can be accelerated through the use of different other tools and techniques. The other two components are enabling environment and conservation values for secured long term conservation. In Nepal, 80 practices (process, methods, actions and good practices) are found implemented for conservation and utilization of native AGRs (Figure 3, Box 1) (Sthapit et al 2006, Joshi et al 2016a, Joshi et al 2017a, Joshi et al 2018, Joshi et al 2019). These practices are selected based on the location and types of AGRs. Among the five conservation components, only two are described below.

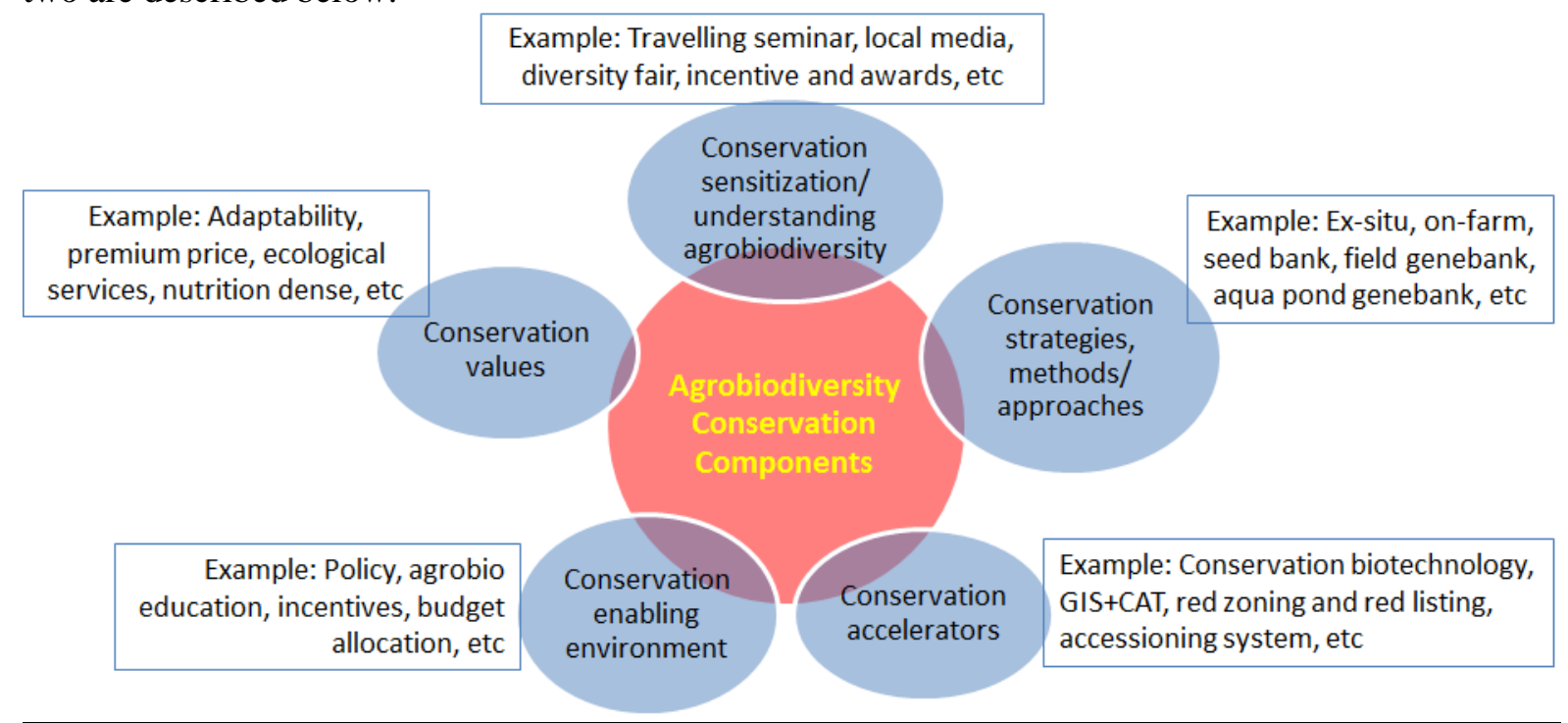

Figure 2. Agrobiodiversity conservation components with examples.

Conservation strategy: Four strategies have been widely used for the management of agrobiodiversity. They are ex-situ, on-farm, in-situ and breeding (Figure 3). Technical differences among these strategies are explained by Joshi and Upadhaya (2019). Breeding strategies have considered evolutionary, diversity and site-specific rather than non-evolutionary, uniformity and wide adaptation approach. 
Conservation methods and approaches: About forty-four different methods for the management of all kinds of AGRs have been developed and adopted in Nepal (Figure 3). Some of them are described in other publications (Sthapit et al 2006, Joshi et al 2016a, Joshi et al 2017a, Joshi and Gauchan 2017, Joshi and Updhaya 2019). The main methods are seed bank for orthodox crops and field genebank for recalcitrant and vegetatively propagated crops, aqua pond genebank for aquatic agricultural animal and plant species, livestock farm genebank for livestock. For insects, mass rearing chamber or automated room can be considered as a method of ex-situ conservation, from where users can get beneficial organisms, usually predators and parasitoids upon formal request. Like insects, pure culture has been widely used to conserve and maintain microbes. At the on-farm level, community seed bank (CSB) and community field genebank (CFGB) are the main methods, which are systems of conservation and utilization of local genetic resources, operated at local levels and run by the community. Among 144 community seed banks in Nepal, 40 are active, six are passive (dormant), 95 are transmuted (transformed) and three are collapsed (Joshi et al 2018). Through 40 CSBs and CFGBs, 2045 accessions are being conserved and they represent from one to 47 different crop species. Conservation related banks are given their names with the prefix of the location followed by the type of bank, for example, Khumal Field Genebank, Khajura Aqua Pond Genebank, Dalchowki Community Seed Bank, Khumal Livestock Farm Genebank, etc.

Some of the notable good practices are red zoning and red listing, diversity fair, germplasm rescue, product diversification, school field genebank, office garden, and temple garden, etc. One of the noteworthy good practice adopted by Entomology Division of NARC is beneficial ex-situ field gene bank for conserving Aphelinus mali (Haldeman), a parasitoid of apple wooly aphid where host insect pests are maintained in an apple orchard in order to make year-round availability of food sources for parasitoids (Mainali et al 2016). Potential conservation methods that are still not established in Nepal are pollen bank, community river, insect park, conservation village, agrobiodiversity trail, and microbial field genebank. Recently, the agro gene sanctuary was established in Khumaltar, Kathmandu. After domestication, agricultural crops never return to nature. Seeds of such crops are kept carefully in manmade houses making sure they do not get chance to interact with nature. The natural evolutionary process is arrested and selection pressure favor to develop one-directional population. Agro Gene Sanctuary is therefore established in Khumaltar to let different crops grow together in more or less natural condition and let their seeds and other parts remain in the same field. It is the field where agricultural plant genetic resources are grown together and allowed to complete their life cycle in the same place over time. Technically it is the method of conservation of cultivated crops and their wild relatives together creating the in-situ condition. Interaction among crops, wild relatives and nature with less human interference may evolve better- adopted genotypes that can be used for research, production, and study. Such a complex gene pool in a single plot may provide genetic resources for researchers and could be a site for evolutionary study. Such an evolutionary field may be the key to developing suitable genotypes in the context of climate change.

Conservation methods and approaches are seed bank, tissue bank, field genebank, community seed bank, community field genebank for crops and forages species; aqua pond genebank and restocking for aquatic agricultural animal and plant species; cryobank and livestock farm genebank for livestock; insect genebank and insect field genebank for insect species, and microbial genebank and microbial field genebank for microorganisms. There are many other such methods and approaches listed in Figure 3 and Box 1. 


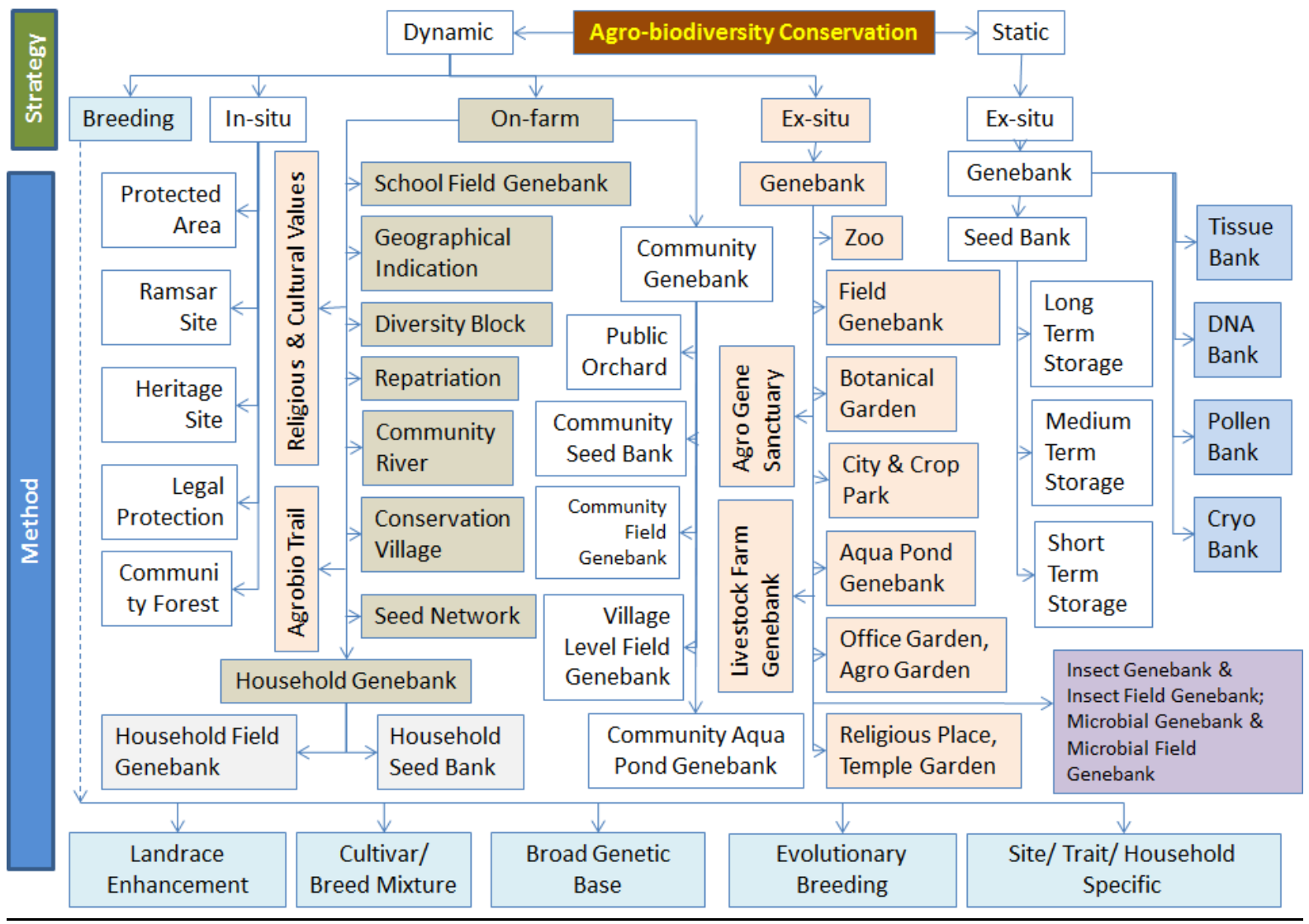

Figure 3. Four agrobiodiversity conservation strategies and 44 methods and approaches.

Source: Sthapit et al 2006, Genebank 2016, Joshi et al 2016a, Joshi et al 2017a, Joshi et al 2019

\begin{tabular}{|c|c|c|}
\hline \multicolumn{3}{|c|}{$\begin{array}{l}\text { Box 1. Additional process, methods, actions and good practices used for conservation and sustainable } \\
\text { utilization of AGRs }\end{array}$} \\
\hline $\begin{array}{l}\text { 1. Accessioning and naming } \\
\text { system }\end{array}$ & $\begin{array}{l}\text { 15. Diversity fair/ seed fair } \\
\text { 16. Food fair \& Himalayan }\end{array}$ & $\begin{array}{l}\text { 28. Landraces catalog, } \\
\text { ownership documentation, }\end{array}$ \\
\hline 2. Agro-plantation & super foods (PQTHN) & \\
\hline 3. Agrobiodiversity rich farmers & 17. Local & 29. Local media for community \\
\hline Incent & 18. Div & \\
\hline $\begin{array}{l}\text { 5. Black box and safety } \\
\text { duplication and backup }\end{array}$ & $\begin{array}{l}\text { 19. Diversity rich solution } \\
\text { 20. Enhancing ecological }\end{array}$ & $\begin{array}{l}\text { grobiodiversity } \\
\text { ent }\end{array}$ \\
\hline 6. Pre breeding \& domestication & services & 31. Dive \\
\hline $\begin{array}{ll}\text { 7. } & \text { GIS + C } \\
\text { 8. } & \text { Restock }\end{array}$ & $\begin{array}{l}\text { 21. Global and national gene } \\
\text { pools }\end{array}$ & $\begin{array}{l}\text { 32. Simplifying the traditional } \\
\text { tech }\end{array}$ \\
\hline 9. Image & 22. Each household as shop & 33. Home stay and market \\
\hline crop herbaria and agro & 23. Particip & \\
\hline muse & 24. Product & $\begin{array}{l}\text { 34. Agrobio poetry and folk } \\
\text { song }\end{array}$ \\
\hline $\begin{array}{l}\text { 12. Germplasm rescue } \\
\text { 13. Agro haat bazaar }\end{array}$ & $\begin{array}{l}\text { 26. Multi- stakeholder and } \\
\text { disciplinary approaches }\end{array}$ & $\begin{array}{l}\text { 35. Sharingshop, writeshop and } \\
\text { virtual workshop }\end{array}$ \\
\hline 14. Site specific staple crop & 27. Agrobio education & 36. Traveling seminar \\
\hline
\end{tabular}

Conservation accelerator: Conservation accelerators are any practices or tools that accelerate the conservation of native AGRs. Some of them are diversity fairs, restocking, marketing, use of modern sciences, etc. Advanced tools such as geographical information system (GIS), climate analog tool (CAT) and biotechnology have been used for better management and utilization of APGRs in Nepal (Chaudhary et al 2016, Joshi et al 2017c, Mainali 2018). GIS is basically applied for collection map, gap analysis, information verification, and diversity analysis. CAT is used to identify analog sites for possible distribution of crops, introduction and repatriation of crop cultivars. NAGRC has developed DNA bank, Tissue bank and DNA fingerprint of some crop landraces (Table 3). 
Conservation Status at National and Intermational Levels

Details of the conservation status of Nepalese AGRs are given in Table 3. Within the country, a total of 18,765 accessions of AGRs have been conserved in 17 different kinds of banks (Joshi et al 2017a, Genebank 2018). A total of 264 agricultural species (ie 4\%) are conserved in different banks. The highest number of conserved species and accessions are of orthodox crops. Conservation of lower plant species, aquatic plants, insects and microorganisms are very low in number. Two tissue banks have conserved 120 accessions of three species (potato, sweet potato and large cardamom). There are 15 field genebanks across the country and 650 accessions of 30 crops are being maintained. DNA bank has maintained 550 accessions of 10 species (rice, cardamom, sugarcane, chayote, pea, garlic, broad leaf mustard, wheat, mango and maize). Thirty accessions of 9 forage species are conserved in Seed Bank. More than 50 species are conserved in different field genebank (Khumal, Bandipur, Lumle and Pakhribas Forage Field Genebank).

There are twenty five domestic animal breeds of eight species identified so far in Nepal. Nineteen accessions of eight livestock species are conserved in Khumal livestock farm genebank. Other existing livestock farm genebanks are Doti for Achhami cattle; Jumla for Baruwal and Bhyanglung sheep, and Sinhal goat; Lumle for Lime and Parkote buffalo, Sinhal goat, and Baruwal and Bhyanglung sheep; Parwanipur for Sakini, Pwankh Ulte and Ghanti Khuile chicken; Tarahara for Nagpuri and Hurrah; Pakhribas for Pakhribas black pig, and Khari goat; Nepalgunj for Tarai goat, and Lampuchhre sheep, and Bandipur for Khari goat (Genebank 2018). Semen of three livestock breeds (Lulu cattle, Achhami cattle and Khari goat) are conserved in cryo bank in Animal Breeding Division (ABD). Conservation of fish species is promoted through restocking of 13 native fish species in Kali Gandaki and five species in Pokhara valley. There are five aqua pond genebanks in Nepal. Khajura aqua pond genebank is conserving four species along with some plant species (lotus, water chestnut, water spinach), Beltari aqua pond genebank has conserved seven species, Pokhara has conserved nine species, Parwanipur aqua pond genebank has conserved six species along with some plant species (fox nut, lotus, water chestnut) and Godawari aqua pond genebank has conserved one native species.

Insect park might be very importance for conservation as well as study. However, only insect field genebank exits where parasitoids are being conserved. Water hyacinth weevil, Neochetina bruchi Hustache, Neochetina eichhorniae Warner, both unintentionally introduced species (from India) and imported species (from USA) are being conserved on the special outdoor structure/chamber in Entomology Division, NARC. Further, isolated insect pathogens are conserved as a means of pure culture. Predators and parasitoids such as Coccinella septempunctata L, Chrysoperla carnea Stephens, Trichogramma chilonis Ishii, Copidosoma koehleri Blanchard, Orgilus lepidus Muesebeck, Neochetina bruchi Hustache, Neochetina eichhorniae Warner, Zygogramma bicolorata Pallister is cultured (mass reared) successfully by Entomology Division, NARC, most of which are exotic in nature. Sixteen species of mushrooms and 8 other microbial species are conserved in microbial genebank (Genebank 2018). Twenty Nepalese accessions of microbes are stored in Japan.

The global genepool is created only of crops and forages species. Safety mechanism has been adopted only in crops and forages species through storing safety backup of 2,045 accessions of eight crops in seven different CGIAR's banks and safety duplicate of 69 accessions of barley in World Seed Vault, Koreas. A total of 24,683 accessions of Nepalese crops, forages and microbes have been conserved in different international and foreign genebanks. Two global databases have maintained 19,200 Nepalese accessions (https://www.genesys-pgr.org/, https://eurisco.ipk-gatersleben.de/apex/f?p=103:1::::::). Indigenous Nepalese fish species Tor putitora (Sahar) was reported in Pakistan and Schizothorax richardsonii (buchhe asala) was reported in Papua New Guinea and Oncorhynchus mykiss (rainbow trout) was reported in Papua New Guinea and Thailand. Two insects, Spenorala rutilans and Lilioceris impressa (F) were exported from Nepal to USA and they successfully mass-reared these species to control skunk vine (Paderia Foetida L.) and air potato (Dioscorea bulbifera L.), respectively (Schmitz 2009). 
Table 3. Nepalese accessions of agricultural genetic resources (crops, forages, livestock, aquatic plant and animal, microorganisms and insects) conserved in National and International Genebanks

\begin{tabular}{|c|c|c|c|c|c|c|}
\hline $\begin{array}{l}\mathbf{S} \\
\mathbf{N}\end{array}$ & Type of bank & $\begin{array}{l}\text { Total } \\
\text { banks, } n\end{array}$ & $\begin{array}{l}\text { Species } \\
\text { conserved, } \mathbf{n}\end{array}$ & $\begin{array}{l}\text { Accession } \\
\text { conserved, } \mathbf{n}\end{array}$ & $\begin{array}{l}\text { Agrobiodiversity } \\
\text { component }\end{array}$ & $\begin{array}{r}\text { Initiated } \\
\text { date }\end{array}$ \\
\hline \multicolumn{7}{|c|}{ National Genepool } \\
\hline 1. & Seed bank & 1 & 105 & 14500 & Orthodox crops & 1986 \\
\hline 2. & Forage seed bank & 1 & 9 & 30 & Orthodox forages & 2010 \\
\hline 3. & Field genebank & 15 & 30 & 650 & $\begin{array}{l}\text { Non-orthodox } \\
\text { crops }\end{array}$ & \\
\hline 4. & Tissue bank & 2 & 3 & 120 & $\begin{array}{l}\text { Non-orthodox } \\
\text { crops }\end{array}$ & 2013 \\
\hline 5. & DNA bank & 1 & 10 & 550 & Crops & 2013 \\
\hline 6. & Forage field genebank & 3 & 50 & 50 & $\begin{array}{l}\text { Non-orthodox } \\
\text { forages }\end{array}$ & 2014 \\
\hline 7. & Crop specific park & 6 & 10 & 450 & $\begin{array}{l}\text { Non-orthodox } \\
\text { crops }\end{array}$ & 2012 \\
\hline 8. & Aqua pond genebank & 5 & 27 & 30 & $\begin{array}{l}\text { Fishes and aquatic } \\
\text { plants }\end{array}$ & 2016 \\
\hline 9. & Cryo bank & 1 & 3 & 3 & Livestock & \\
\hline 10. & $\begin{array}{l}\text { Livestock farm } \\
\text { genebank }\end{array}$ & 10 & 8 & 38 & Livestock & 2016 \\
\hline 11. & Agro gene sanctuary & 1 & 10 & 25 & Crops & 2018 \\
\hline 12. & Microbial genebank & 1 & 24 & 24 & Micro organisms & 2018 \\
\hline & Insect field genebank & 1 & 11 & 11 & Insects & 2018 \\
\hline 14. & Community seed bank & 40 & 50 & 2045 & Crops & 1994 \\
\hline & $\begin{array}{l}\text { Community field } \\
\text { genebank }\end{array}$ & 8 & 15 & 113 & $\begin{array}{l}\text { Non-orthodox } \\
\text { crops }\end{array}$ & 2012 \\
\hline 16. & School field genebank & 7 & 15 & 122 & $\begin{array}{l}\text { Non-orthodox } \\
\text { crops }\end{array}$ & 2014 \\
\hline 17. & $\begin{array}{l}\text { Protected area (in-situ } \\
\text { bank) }\end{array}$ & 10 & 4 & 4 & Crop wild relatives & 2018 \\
\hline \multicolumn{7}{|c|}{ Global genepool (outside country) } \\
\hline & $\begin{array}{l}\text { World Seed Vault, } \\
\text { Korea (Safety } \\
\text { duplicates) }\end{array}$ & 1 & 1 & 69 & Barley & 2014 \\
\hline 19. & AVRDC, Taiwan & 1 & NK & 930 & Vegetables & NK \\
\hline 20. & NIAS, Japan & 1 & NK & 4136 & Crops & NK \\
\hline & NIAS, Japan & 1 & NK & 20 & Microbes & NK \\
\hline & USDA, USA & 1 & NK & 2781 & Crops & NK \\
\hline & NBPGR, India & 1 & NK & 3000 & Crops & NK \\
\hline & CGIAR Banks & 11 & NK & 11702 & Crops and forages & NK \\
\hline & $\begin{array}{l}\text { Safety backup } \\
\text { (CGIAR Banks) }\end{array}$ & 7 & 8 & 2045 & Crops & 2013 \\
\hline 26. & MLS-ITPGRFA & 1 & 20 & 614 & Crops and forages & 2017 \\
\hline \multicolumn{7}{|c|}{ Nepalese accessions at global database } \\
\hline 27. & GENESYS & 1 & NK & 15511 & Crops and forages & NK \\
\hline 28. & EURISCO & 1 & NK & 3689 & Crops and forages & NK \\
\hline
\end{tabular}

NK, Not known.

Sources: Joshi 2017, Joshi et al 2017a, Joshi et al 2018, Genebank 2018, Joshi and Upadhaya 2019.

\section{Challenges and Issues}

Nepal is an agrobiodiversity rich country but native genetic resources never got priority in research, education and development, resulted in genetic erosion. Major challenges are to stop genetic erosion, to make native AGRs competitive, to decrease the current 95-100\% dependency (Joshi et al 2017d) on foreign germplasm, to secure food and nutrition conserving existing agrobiodiversity, to replace foreign agriculture products and germplasm by native AGRs and their products, to identify global potential native AGRs and market globally, to develop site-specific different products, to create 
enabling environment for favoring diversity rich varieties, breeds and strains to accelerate the evolutionary population to capture diversity from wide range of agricultural areas, etc.

There is a need of extensive characterization, evaluation, and tagging of economically important traits. Adulteration by foreign germplasm needs to be minimized and education system should be revised to improve the traditional technologies rather than replacing native technologies including native AGRs. Alternative of many large scale production of monogenotyped variety or breed should be identified for sustainable agriculture and to diversify the products. Documents related to ownership of the landraces needs to be developed. Evidence of association of landraces with geography and cultural value need to be explored. An online database should be established to facilitate access to germplasm. Mountain areas are good for producing Himalayan super foods that are better in terms of purity, quality, taste, health and nutrition. Many potential wild AGRs exist in the country and research is necessary for domestication and commercialization.

\section{CONCLUSION}

Mainly because of neglected and underutilization of $85 \%$ native AGRs, $40 \%$ of diversity has been lost. Conservation work, therefore, should get priority. About 5-15\% of native AGRs, depending on specific AGR, has been used in research and development. Priority for conservation and utilization should be given to native AGRs focusing on developing site-specific staple AGRs, marketing globally by involving all relevant stakeholders. Eighty process, methods, actions and good practices need to be scaled up widely for effectively conserving AGRs. Only 4\% of total agricultural species have been conserved that demand to accelerate the conservation works in the country. To prioritize the AGRs for conservation, diversity should be assessed at all five levels ie agroecosystem, species, variety/breed/strain, genotype and allele. Agricultural science needs to advance on native AGRs.

\section{ACKNOWLEDGEMENTS}

A large number of farmers and experts have been involved in generating information and implementing different actions including good practices and they all are highly acknowledged. Special thanks go to Bhola Shrestha, Tek Bahadur Gurung, Ajaya Chaudhary, Harish Chandra Bastola, Anil Acharya, Bidya Pandey, Hari Bahadur KC, Suraj Baidya, Shree Prasad Vista and Prem Nidhi Sharma. Some good practices and actions were implemented with the financial support from NARC, LI-BIRD, Bioversity International, MoAD, IUCN, MoFSC, IAAS, Parivartan Nepal and DoA.

\section{REFERENCES}

Abington JB, ed. 1992. Sustainable Livestock Production in the Mountain Agro-ecosystem of Nepal. Animal Production and Health Paper 105. FAO, Rome.

Acharya LN and PN Atreya. 2012. Fruit development in Nepal: Past, efforts, present status and future needs/ way forward. In: Proc. $8^{\text {th }}$ national horticultural seminar on horticultural development towards the pace of national economic growth (SM Sakhya, KP Paudel, BB Khatri, BK Paudel, IR Pandey, eds). Nepal Horticulture Society, Lalitpur.

Arjyal C, BN Dahal and B Khadka. 2004. Microbial quality of milk available in Kathmandu valley. Journal of Nepal Medical Association, 43:137-140. DOI: https://doi.org/10.31729/jnma.475

Aryal S, G Karki and S Pandey. 2015. Microbial diversity in freshwater and marine environment. Nepal J. Biotechnol. 3:68-70

Banwart GJ. 1989. Useful Microorganisms. In: Basic Food Microbiology. Springer, Boston, MA; pp.433-504.

Bhattarai A, B Bhattarai and S Pandey. 2015. Variation of soil microbial population in different soil horizons. J Microbiol Exp. 2(2):75-78. DOI: https://doi.org/10.15406/jmen.2015.02.00044

Chaudhary P, BK Joshi, K Thapa, R Devkota, KH Ghimire, K Khadka, D Upadhya and R Vernooy. 2016. Interdependence on plant genetic resources in light of climate change. In: Implementing the International Treaty on Plant Genetic Resources for Food and Agriculture in Nepal: Achievements and Challenges (BK Joshi, P Chaudhary, D Upadhya and R Vernooy, eds). LIBIRD, Pokhara; NARC, MoAD, Kathmandu and Bioversity International, Rome; Nepal, pp.65-80.

Chaudhary P, D Gauchan, RB Rana, BR Sthapit and DI Jarvis. 2004. Potential Loss of Rice Landraces from A Terai Community in Nepal: A Case Study from Kachorwa, Bara. Plant Genetic Resources Newsletter 137:1-18. 
Christensen M, S Devkota, S Bhattarai and HO Larsen. 2008. Collection and use of wild edible fungi in Nepal. Econ Bot 62:12-23

FAO. 1999. Women: Users, preservers and managers of agrobiodiversity. http://www.fao.org/3/x0171e/x0171e03.htm

FAO. 2010. The Second Report on the State of the World's Plant Genetic Resources for Food and Agriculture. Rome

FAO. 2019. The State of the World's Aquatic Genetic Resources for Food and Agriculture. FAO Commission on Genetic Resources for Food and Agriculture assessments. Rome.

Genebank. 2016. Annual Report 2072/73 (2015/16). National Agriculture Genetic Resources Centre, NARC Khumaltar, Lalitpur, Nepal.

Genebank. 2018. Annual Report 2074/75 (2017/18). National Agriculture Genetic Resources Centre, NARC. Khumaltar, Lalitpur, Nepal.

Ghimire KH and BK Joshi. 2019. Crop groups based on conservation strategy. In: Working groups of agricultural plant genetic resources (APGRs) in Nepal (BK Joshi and R Shrestha, eds). Proceedings of a National Workshop, 21-22 June 2018, Kathmandu; pp.174-183.

Gotame TP, KP Paudyal and PP Khatiwada. 2014. Status of Fruit and Nut Genetic Resources in Nepal. Horticulture Research Division, NARC, Khumaltar.

Gurung TB. 2017. Chapter III. Aquatic biodiversity for food and agriculture in Nepal. In: The state of Nepal's biodiversity for food and agriculture (BK Joshi, AK Acharya, D Gauchan and P Chaudhary, eds). Ministry of Agricultural Development, Kathmandu, Nepal; pp.37-48.

http://moad.gov.np/public/uploads/974648021-SoNBFA_Nepal.pdf

Husen A. 2019. Status of ornamental fish import, research and scope in Nepal. Research Journal of Animal, Veterinary and Fishery Science. 7(1):6-9.

Joshi BK and D Gauchan. 2017. Germplasm Rescue: Why and How? In: Rebuilding Local Seed System of Native Crops in Earthquake Affected Areas of Nepal (BK Joshi and D Gauchan, eds). Proceedings of a National Sharingshop, 18 Dec 2017, Kathmandu; NAGRC, Bioversity International and Crop Trust; Kathmandu, Nepal; pp.41-50. https://www.bioversityinternational.org/elibrary/publications/detail/rebuilding-local-seed-system-of-native-crops-in-earthquake-affected-areas-ofnepal/

Joshi BK and D Upadhaya. 2019. On-farm Conservation Approaches for Agricultural Biodiversity in Nepal. Journal of Agriculture and Natural Resources 2: 14-35. DOI: https://doi.org/10.3126/janr.v2i1.26012

Joshi BK, AK Acharya, D Gauchan and MR Bhatta. 2017a. Agrobiodiversity status and conservation options and methods. In: Conservation and Utilization of Agricultural Plant Genetic Resources in Nepal (BK Joshi, HB KC and AK Acharya, eds). Proceedings of 2nd National Workshop, 22-23 May 2017, Dhulikhel; NAGRC, FDD, DoA and MoAD; Kathmandu, Nepal; pp. 21-38. http://moad.gov.np/public/uploads/855517450-Plant\%20Genetic\%20Resources_CUAPGR_Nepal-min.pdf

Joshi BK, AK Acharya, D Gauchan, D Singh, KH Ghimire and BR Sthapit. 2017b. Geographical indication: A tool for supporting on-farm conservation of crop landraces and for rural development. In: Conservation and Utilization of Agricultural Plant Genetic Resources in Nepal (BK Joshi, HB KC and AK Acharya, eds). Proceedings of 2nd National Workshop, 22-23 May 2017, Dhulikhel; NAGRC, FDD, DoA and MoAD; Kathmandu, Nepal; pp.50-62. http://moad.gov.np/public/uploads/855517450-

Plant\%20Genetic\%20Resources_CUAPGR_Nepal-min.pdf

Joshi BK, D Singh, P Chaudhary, KH Ghimireand M Khanal. 2017c. Biotechnology, geographical information system and climate analog tool for management of APGRs. In: Conservation and Utilization of Agricultural Plant Genetic Resources in Nepal (BK Joshi, HB KC and AK Acharya, eds). Proceedings of $2^{\text {nd }}$ National Workshop, 22-23 May 2017, Dhulikhel; NAGRC, FDD, DoA and MoAD; Kathmandu, Nepal; pp.156-169. http://moad.gov.np/public/uploads/855517450Plant\%20Genetic\%20Resources_CUAPGR_Nepal-min.pdf

Joshi BK, KH Ghimire and D Singh. 2016a. Conservation options, methods and programs for agricultural plant genetic resources in Nepal. National Agriculture Genetic Resources Center, Khumaltar.

Joshi BK, KH Ghimire and D Singh. 2018. The National Genebank's Promotion of Community Seed Banks: Status and Strategy. In: Community Seed Banks in Nepal (BK Joshi, P Shrestha, D Gauchan and R Vernooy, eds). $2^{\text {nd }}$ National Workshop Proceedings, 3-5 May 2018, Kathmandu Nepal; NAGRC, LI-BIRD and Bioversity International; Kathmandu, Nepal; pp. 21-44

Joshi BK, MP Upadhyay D Gauchan, BR Sthapit and KD Joshi. 2004. Red listing of agricultural crop species, varieties and landraces. Nepal Agric. Res. J. 5:73-80.

Joshi BK, R Shrestha, IP Gautam, AP Poudel and TP Gotame. 2019. Neglected and Underutilized Species (NUS), and Future Smart Food (FSF) in Nepal. National Agriculture Genetic Resources Center (NAGRC, National Genebank), NARC, Khumaltar, Kathmandu, Nepal.

Joshi BK, R Vernooy and P Chaudhary. 2017d. Crop Interdependence, Adaptation to Climate Change and the 
Multilateral Systems of Access and Benefit Sharing: The Case of Nepal. Indian Journal of Plant genetic Resources 30(3):210-217. DOI: https://doi.org/10.5958/0976-1926.2017.00026.2

Joshi BK. 2017a. Plant Breeding in Nepal: Past, Present and Future. Journal of Agriculture and Forestry University 1:1-33. http://afu.edu.np/sites/default/files/Plant_breeding_in_Nepal_Past_Present_and_Future_BK_Joshi.pdf

Joshi BK. 2017b. Conservation and utilization of agro-biodiversity advanced from 1937 to 2017 in Nepal. In: Krishi Sanchar Smarika (F Devkota, ed). Agricultural Information and Communication Center (AICC), MoAD, Khumaltar; pp.181-208.

https://www.researchgate.net/publication/318316609_Conservation_and_Utilization_of_AgroBiodiversity_Advanced_from_1937_to_2017_in_Nepal

Joshi SL, RB Thapa and S Bista, eds. 2016b. Proceedings of Workshop on Review and Strategy Development of Entomological Research Works in Nepal (Volume 1), 4-6 March 2012, Entomology Division, Khumaltar, Lalitpur, Nepal.

Joshi SL, RB Thapa and S Bista, eds. 2016c. Proceedings of Workshop on Review and Strategy Development of Entomological Research Works in Nepal (Volume 1), 4-6 March 2012, Entomology Division, Khumaltar, Lalitpur, Nepal.

Joshi SL. 2016. Biological control of agricultural insect pests in Nepal: Present status and future prospects. In: Proceedings of Workshop on Review and Strategy Development of Entomological Research Works in Nepal (Volume 1) (SL Joshi, RB Thapa and S Bista, eds). 4-6 March 2012, Entomology Division, Khumaltar, Lalitpur, Nepal.

Limbu JH, N Chapagain, SK Gupta and S Sunuwar. 2019. Review on fish diversity of eastern Nepal. International Journal of Fisheries and Aquatic Studies 7(3):177-181.

Mainali RP, SB Pradha and ASR Bajracharya. 2016. Entomological research on fruit crop in Nepal: A review. Proceedings of Workshop on Review and Strategy Development of Entomological Research Works in Nepal, 4-6 March 2012, Entomology Division, Khumaltar, Nepal; pp.191-198.

Mainali RP. 2018. Setting conservation priorities for crop wild relatives of important food security crops of Nepal. MS Thesis. Wageningen University and Research. Wageningen, the Netherlands.

MoAC. 2004. Country Report on Animal Genetic Resources of Nepal. Ministry of Agriculture and Cooperatives, Singha Durbar, Kathmandu, Nepal.

MoFSC. 2014. Nepal Biodiversity Strategy and Action Plan 2014-2020. Government of Nepal, Ministry of Forests and Soil Conservation, Kathmandu, Nepal.

Møller AP. 2019. Parallel declines in abundance of insects and insectivorous birds in Denmark over 22 years. Ecology and Evolution 9: 6581-6587. DOI: https://doi.org/10.1002/ece3.5236

Niroula B and KLB Singh. 2011. Aquatic plant resources of Betana Wetland, Morang, Nepal. Our Nature 9: $146-155$.

Paudel KC and BN Tiwari. 1992. Chapter 7. Fodder and Forage Production. In: Sustainable Livestock Production in the Mountain Agro-ecosystem of Nepal (JB Abington, ed). Animal Production and Health Paper 105. FAO, Rome.

Paudel LN. 2017. Chapter II. Animal Biodiversity for Food and Agriculture in Nepal. In: The state of Nepal's biodiversity for food and agriculture (BK Joshi, AK Acharya, D Gauchan and P Chaudhary, eds). Ministry of Agricultural Development, Kathmandu, Nepal; pp.25-36. http://moad.gov.np/public/uploads/974648021-SoNBFA_Nepal.pdf

Raut JK. 2014. The proceedings of the seminar on mushroom consumption and poisoning risk. 14 January 2014; Nepal Academy of Science and Technology, Khumaltar, Lalitpur

Regmi PP. 1982. An Introduction to Nepalese Foods Plants. Royal Nepal Academy, Kathmandu, Nepal

Schmitz DC. 2009. Upland Plants: Air Potato. Research Program Newsletter, Division of Habitat and Species Conservation. Florida Fish and Wildlife Conservation Commission, Invasive Plant Management Section, Commonwealth. Blvd., MS 705, Tallahassee, FL 32399.

Seibold S, MM Gossner, NK Simons et al. 2019. Arthropod decline in grasslands and forests is associated with landscape-level drivers. Nature 574: 671-674. DOI: https://doi.org/10.1038/s41586-019-1684-3.

Sharma U. 2007. Medicinal and Aromatic Plants: a Growing Commercial Sector of Nepal. The Initiation 1:4-8.

Shimada T and BMS Basnet. 2015. A list of cultivated and edible wild plants in Nepal. Lochan Gyawali, Jagadamba Press, Lalitpur.

Shrestha J. 1999. Cold water fish and fisheries in Nepal. In: Fish and fisheries at higher altitudes: Asia (T Pedr, ed). FAO Fisheries Technical Paper. No. 385. FAO, Rome, FAO; pp.13-40.

Shrestha R and B Shrestha, eds. 1999. Wild Relatives of Cultivated Plants in Nepal. Proc. National Conference, June 2-4, 1999 Kathmandu, GEM-Nepal.

Smith BD, B Bhandari and K Sapkota. 1996. Aquatic biodiversity in the Karnali and Narayani river basins Nepal. IUCN Nepal, Kathmandu. 
Sthapit BR, P Shrestha and MP Upadhyay, eds. 2006. On-farm Management of Agricultural Biodiversity in Nepal: Good Practices. NARC/LI-BIRD/Bioversity International, Nepal.

Strain D. 2011. 8.7 million: A new estimate for all the complex species on Earth. Science 333 (6046), pp. 1083. DOI: https://doi.org/10.1126/science.333.6046.1083.

Subba BR, N Pokharel and MR Pandey. 2017. Ichthyofaunal diversity of Morang district, Nepal. Our Nature 15(1-2):55-67. DOI: https://doi.org/10.3126/on.v15il-2. 18794.

Sweetlove L. 2011. Number of species on Earth tagged at 8.7 million. Nature. DOI: https://doi.org/10.1038/news.2011.498.

Takeda K, Satoh M, Neopane SP, Kuwar BS, Joshi HD, Shrestha NP, Fujise H, Tasai M, Tagami T, Hanada H. 2004. Mitochondrial DNA analysis of Nepalese domestic dwarf cattle Lulu. Anim. Sci. J. 75:103-110.

Thapa VK. 1997. An inventory of Nepal's insects. Vol 1. IUCN Nepal, Kathmandu

Upadhyay MP and BK Joshi. 2003. Plant Genetic Resources in SAARC Countries: Their Conservation and Management: Nepal Chapter. SAARC Agriculture Information Center, pp.297-422.

Upadhyay MP, HK Saiju, BK Baniya and MS Bista, eds. 1995. Plant Genetic Resources: Nepalese Perspective. Proc. National Workshop PGR Conservation, Use and Management, 28 Nov-1 Dec 1994, Kathmandu. NARC, IPGRI.

Van Huis A, JV Itterbeeck, H Klunder, E Mertens, A Halloran, G Muirand and P Vantomme. 2013. Edible insects: Future prospects for food and feed security. FAO Forestry Paper 171. FAO, Rome.

Wilson RT. 1997. Animal genetic resources and domestic animal diversity in Nepal. Biodiversity and Conservation 6: 233-251.

Wilson RT. 2017. Domestic livestock in Nepal: Production systems, genetic resources, research and the way forward. International Journal of Agricultural Management 6 (2): 50-61. DOI: https://doi.org/10.5836/ijam/2017-06-50

Yami KD, S Bhattarai and S Adhikari. 2003. Vermicomposting and Micro Flora Analysis of Vermicompost, Vermicast and Gut of Red Earthworm. Nepal Journal of Science and Technology 5: 121-126. 
Annex I. Some important indigenous genotypes of agronomic crops, horticultural crops, forage species, livestock species, aquatic agricultural species, insects and microorganisms

\begin{tabular}{|c|c|c|c|c|}
\hline SN & English name & Nepali name & Scientific name & Most important landraces \\
\hline \multicolumn{5}{|c|}{ Agronomic crops } \\
\hline 1. & Amaranth & Latte & Amaranthus spp & Kalo, Seto, Jhule, Rato, Hariyo \\
\hline 2. & Barley & Jau & Hordeum vulgare $\mathrm{L}$ & Chawali, Lekali, Taakullo, Tude \\
\hline 3. & Bean & Simi & Phaseolus spp & $\begin{array}{l}\text { Hiude Simi, Seto Simi, Gahate Simi, } \\
\text { Taati Simi, Jire Simi }\end{array}$ \\
\hline 4. & Black gram & Maas & Vigna mungo (L.) Hepper Wild & Kaalo, Khairo, Saano, Thulo \\
\hline 5. & Broad bean & Bakulaa & Vicia faba L. & Saano, Thulo \\
\hline 6. & Buckwheat & Faapar & Fagopyrum spp & Tite Faper, Mithe, Bhate, Bharule \\
\hline 7. & Cowpea & Bodi & Vigna unguiculata (L.) Walp. & $\begin{array}{l}\text { Tane Bodi, Katike Bodi, Gaajale Bodi, } \\
\text { Makai Bodi, Fokse Bodi, Seto Bodi }\end{array}$ \\
\hline 8. & Finger millet & Kodo & Eleusine coracana (L.) Gaertn. & $\begin{array}{l}\text { Dalle, Mudke, Samdhi, Nagre, Padure, } \\
\text { Seto Kodo }\end{array}$ \\
\hline 9. & Foxtail millet & Kaguno & Setaria italica (L.) Beauv. & $\begin{array}{l}\text { Raato, Aule, Kaalo, Pahenlo, Saano, } \\
\text { Seto }\end{array}$ \\
\hline 10. & $\begin{array}{l}\text { Groundnut, } \\
\text { peanut }\end{array}$ & Badaam & Arachis hypogaea L. & Thuli, Saano \\
\hline 11. & Horsegram & Gahat & $\begin{array}{l}\text { Macrotyloma uniflorum (Lam.) } \\
\text { Verdc. }\end{array}$ & Khairo, Raato, Saano \\
\hline 12. & Indian Mustard & $\begin{array}{l}\text { Rayo, rai, } \\
\text { raichi, tora, } \\
\text { barsale }\end{array}$ & $\begin{array}{l}\text { Brassica juncea (L.) Czern. \& } \\
\text { Coss. }\end{array}$ & $\begin{array}{l}\text { Raayo, Gujmuje, Kaade, Thulo Paate, } \\
\text { Kaalo, Raato }\end{array}$ \\
\hline 13. & Lentil & Musuro & Lens culinaris Medikus & $\begin{array}{l}\text { Kaalo Musuro, Khairo Musuro, Saano, } \\
\text { Thulo }\end{array}$ \\
\hline 14. & Maize & Makai & Zea mays L. & Sathiya, Murali, Thulo Pahelo, Seto \\
\hline 15. & Pea & Matar kerau & Pisum sativum L. & Saano, Thulo, Hariyo, Lahare \\
\hline 16. & Pigeonpea & Rahar & Cajanus cajan (L.) Millsp. & $\begin{array}{l}\text { Raato, Seto, Chanki, Pjawa, Chaite, } \\
\text { Lalkaa, Baisaakhi }\end{array}$ \\
\hline 17. & Proso millet & Chino & Panicum miliaceum L. & Dudhe, Haade, Raato, Kaptade \\
\hline 18. & Rapeseed & Tori & Brassica rapa L. & Kala, Pilaa \\
\hline 19. & Rice & Dhaan & Orzya sativa L. & $\begin{array}{l}\text { Jumli Maarshi, Kalanamak, Ekle, } \\
\text { Bhaati, Jethobudo, Anadi, Aapjutte, } \\
\text { Ghaiya, Gurdi, Jhinuwa, Lalka } \\
\text { Basmati, Samundraphini, Pahele, } \\
\text { Nakhisaro, Giupuri, Tilki, } \\
\text { Krishnabhog }\end{array}$ \\
\hline 20. & Soybean & Bhatmas & Glycine max (L.) Merrl. & $\begin{array}{l}\text { Seto, Kaanchi, Thulo, Kaalo, Saano, } \\
\text { Khairo }\end{array}$ \\
\hline 21. & Wheat & Gahu & Triticum aestivum $L$ & $\begin{array}{l}\text { Nafal, Mudule, Hansaa, Daabdi, } \\
\text { Pawai, Saano, Raani, Jhuse, Bhote, } \\
\text { Dudhe }\end{array}$ \\
\hline \multicolumn{5}{|c|}{ Fruit crops } \\
\hline 22. & Apple & Shyau & Malus pumila Mill. & $\begin{array}{l}\text { Dolpa Local, Helambu Local, Marpha } \\
\text { Shyau, Jumla Shyau }\end{array}$ \\
\hline 23. & Apricot & Khurpaani & Prunus armeniaca Linn. & $\begin{array}{l}\text { Humla Local, Jumla Local, Kakani } \\
\text { Local }\end{array}$ \\
\hline 24. & Banana & Keraa & Musa paradisiaca L. & $\begin{array}{l}\text { Mungre Kera, Local Maalbhog Kera, } \\
\text { Jhaapali Maalbhog, Ghiu Keraa }\end{array}$ \\
\hline 25. & Guava & $\begin{array}{l}\text { Aamba, } \\
\text { belauti }\end{array}$ & Psidium guajava L. & Dhunibeshi Ko Aamba \\
\hline 26. & Jack fruit & Katahar & Artrocrappus heterophyllus & Tarai Local \\
\hline 27. & Lemon & Nibuwa & Citrus limon (L.) Osbeck & Hill Lemon, Nepali Oblong \\
\hline 28. & $\begin{array}{l}\text { Mandari } \\
\text { Orange }\end{array}$ & Suntalaa & Citrus reticulata Blanco & $\begin{array}{l}\text { Manakamana Local, Dhankuta Local, } \\
\text { Ramjattar Local }\end{array}$ \\
\hline 29. & Mango & Aap & Mangifera indica L. & Siraha Local, Bhadaure, Supare \\
\hline 30. & Pear & Naashpati & Pyrus pyrifolia & Pharping Local \\
\hline 31. & Pomegranate & Daarim & Punica granatum & Nepaali Daarim \\
\hline 32. & $\begin{array}{l}\text { Sugar apple, } \\
\text { custard apple }\end{array}$ & $\begin{array}{l}\text { Raam phal or } \\
\text { sarifaa }\end{array}$ & Annona squamosa Linn. & Sarifa \\
\hline 33. & Sweet orange & Junaar & Citrus sinensis (L.) Osbeck & Sindhuli Local, Dadeldhura Local \\
\hline 34. & Walnut & Okhar & Juglans regia L. & Hard Shelled Okhar \\
\hline \multicolumn{5}{|c|}{ Vegetable crops } \\
\hline 35. & Bean & Simi & Vicia faba L. & Jumla Local, Mustang Local, Humla \\
\hline
\end{tabular}




\begin{tabular}{|c|c|c|c|c|}
\hline SN & English name & Nepali name & Scientific name & Most important landraces \\
\hline & & & & $\begin{array}{l}\text { Local, Karnani Simi, Jumli Simi, } \\
\text { Gatlange Simi, Asare Simi }\end{array}$ \\
\hline 36. & Brinjal & $\begin{array}{l}\text { Bhentaa, } \\
\text { baijan }\end{array}$ & Solanum melongena L. & Birgunj Local \\
\hline 37. & Chilli & Khursaani & Capsicum frutescens L. & $\begin{array}{l}\text { Jhyanmara Thalle Khursani, Akabare } \\
\text { Khursani, Jire Khursani }\end{array}$ \\
\hline 38. & Cucumber & Kaakro & Cucumis sativus L. & Madale Kakro \\
\hline 39. & Garlic & Lasun & Allium sativum L.) & $\begin{array}{l}\text { Kirtipur Local, Bhaktapur Local, } \\
\text { Bhote Lasun, Sthaniya Bose, Tarai } \\
\text { Lasun }\end{array}$ \\
\hline 40. & Ginger & Adhuwa & Zingiber officinale Roscoe & Bhose Adhuwa \\
\hline 41. & $\begin{array}{l}\text { Large } \\
\text { Cardamom }\end{array}$ & Alaichi & Amomum sabulatum Roxb & Jirmale, Bharlange, Salakpure, Saaune \\
\hline 42. & Lettuce & Latte ko saag & Latuca sativa & Ramechhap Hariyo \\
\hline 43. & Potato & Aalu & Solanum tuberosum & $\begin{array}{l}\text { Mude Local, Tharu Aalu, Helambu } \\
\text { Local, Sidhuwa Local, Dhorpatan } \\
\text { Local }\end{array}$ \\
\hline 44. & Radish & Mulaa & Raphanus sativus L. & Pyuthane Local, Choto \\
\hline 45. & Sponge Gourd & Ghiraulaa & Luffa cylindrica & Basaune Ghiraula \\
\hline 46. & Taro & Pidaalu & Colocasia esculenta (L.) Schott & $\begin{array}{l}\text { Thado Mukhe, Hatti Paaile, Sath } \\
\text { Mukhe, Gante Pancha Mukhi, Chatre, } \\
\text { Dudhe Pidalu, Khari Pidalu, Gandaki } \\
\text { Hattipau }\end{array}$ \\
\hline 47. & Tomato & Golbedaa & Lycopersicon lycopersicum & Lasi Gede \\
\hline \multicolumn{5}{|c|}{ Forage genetic resources } \\
\hline 48. & Barro & Barro & Terminalia bellirica & Barro \\
\hline 49. & Bermuda & Dubo & Cynodon dactylon L. pres. & Dubo \\
\hline 50 . & Black Siris & Kalo Siris & Albizia lebbek & Kalo Siris \\
\hline 51. & Broom Grass & Amrisho & Thysanolaena maxima & Amrisho \\
\hline 52. & Chuletro & Chuletro & Brassiopsis hainla & Chuletro \\
\hline 53. & Coral Tree & Faledo & Erythrina strica/varigata & Faledo \\
\hline 54. & Cutch tree & Khayar & Acacia catechu (L.f.) Wild. & Khayar \\
\hline 55. & Dudhilo & Dudhilo & Ficus nemoralis & Dudhilo \\
\hline 56. & Dumri & Dumri & Ficus racemosa & Dumri \\
\hline 57. & Elephant fig & Kabro & Ficus lacor Buch.-Ham & Kabro \\
\hline 58. & Fodder fig & Khanaayo & $\begin{array}{l}\text { Ficus semicordata Buch.-Ham ex } \\
\text { Sm. }\end{array}$ & Khanaayo \\
\hline 59. & Gogan & Gogan & Saurauia nepaulensis DC. & Gogan \\
\hline 60. & Harro & Harro & Terminalia chebula & Harro \\
\hline 61. & Kans & Kans & Saccharum spontaneum & Kans \\
\hline 62. & Khasreto & Khasreto & Ficus hispida & Khasreto, Gelido \\
\hline 63. & Khasru & Khasru & Quercus semecarpifolia & Khasru \\
\hline 64. & $\begin{array}{l}\text { Leucaena/ Ipil- } \\
\text { Ipil }\end{array}$ & Ipil-Ipil & Leucaena leucocephala & Ipil-Ipil \\
\hline 65. & Litsea & Kutmero & Litsea monopetala (Roxb.) Pers. & Kutmero, Kutmiro \\
\hline 66. & Monkey jack & Badahar & $\begin{array}{l}\text { Artocarpus lakoocha Wall. ex } \\
\text { Roxb. }\end{array}$ & Badahar \\
\hline 67. & $\begin{array}{l}\text { Mountain } \\
\text { ebony }\end{array}$ & Koiralo & Bauhinia variegate L. & Koiralo \\
\hline 68. & Mulberry & Kimbu & Morus alba & Kimbu \\
\hline 69. & Nevaro & Nevaro & Ficus rosenbergii & Nevaro, Nimaro \\
\hline 70. & Oat & Jai & Avena sativa L. & Jai \\
\hline 71. & Pakhauri & Pakhauri & Ficus glaberrima & Pakhauri \\
\hline 72. & $\begin{array}{l}\text { Pink bauhinia, } \\
\text { Ebony }\end{array}$ & Taankee & Bauhinia purpurea L. & Taankee \\
\hline 73. & Premna & Ginderi & Premna integrifolia & Ginderi \\
\hline 74. & Red clover & Rato clover & Trifolium pretense L. & Rato clover \\
\hline 75. & $\begin{array}{l}\text { Sacrificial } \\
\text { grass }\end{array}$ & Kush & $\begin{array}{l}\text { Desmostachys bipinnata (L.) } \\
\text { Stapf }\end{array}$ & Kush \\
\hline 76. & Siru & Siru & Imperata cylindrica & Siru \\
\hline 77. & Tatelo & Tatelo & Oroxylum indicum (L.) Kurz & Tatelo \\
\hline 78. & $\begin{array}{l}\text { Weeping } \\
\text { willow }\end{array}$ & Bains & Salix babylonica L. & Bains \\
\hline 79. & White clover, & Pyauli & Trifolium repens L. & Pyauli, Beuli Jhar \\
\hline
\end{tabular}




\begin{tabular}{|c|c|c|c|c|}
\hline SN & English name & Nepali name & Scientific name & Most important landraces \\
\hline \multicolumn{5}{|c|}{ Ladino } \\
\hline 80. & $\begin{array}{l}\text { Wild sugarcane } \\
\text { grass, thatch } \\
\text { grass }\end{array}$ & Kaans & Saccharum spontaneum L. & Kaans \\
\hline 81. & Wodier & Dabdabe & $\begin{array}{l}\text { Lannea coromandelica (Houtt.) } \\
\text { Merr. }\end{array}$ & Dabdabe \\
\hline \multicolumn{5}{|c|}{ Livestock genetic resources } \\
\hline 82. & Buffalo & Bhainsi & Bubalus bubalis & Lime, Parkote, Gaddi, Tarai \\
\hline 83. & Cattle & Gai & Bos indicus & Siri, Achhami, Khaila, Pahadi, Tarai \\
\hline 84. & Cattle & & Bos taurus & Lulu \\
\hline 85. & Chicken (fowl) & Kukhura & Gallus domesticus & Sakini, Pwankh Ulte, Ghanti Khuile \\
\hline 86. & Donkey, ass & Gadhaa & Equus asinus & Gadhaa \\
\hline 87. & Duck & Haans & Anas platyrhyncos & Haans \\
\hline 88. & Goat & Bakhra & Capra hircus & Chyangra, Sinhal, Khari, Tarai \\
\hline 89. & Guinea fowl & Laukaat & Numida meleagris & Laukaat \\
\hline 90. & Horse & Ghonda & Equus caballus & Jumli Ghoda \\
\hline 91. & Mule & Khachhar & Horse $\mathrm{x}$ donkey & Khachhar \\
\hline 92. & Pig & Sungur & Sus scrofa domesticus & $\begin{array}{l}\text { Chwanche, Bampudke, Hurrah, } \\
\text { Nagpuri }\end{array}$ \\
\hline 93. & Pony & Tattu & Equus ferus caballus & Tattu \\
\hline 94. & Sheep & Bhainda & Ovis aries & $\begin{array}{l}\text { Bhyanglung, Baruwal, Kage, } \\
\text { Lampuchhre }\end{array}$ \\
\hline 95. & Yak & Yak & Bos gruniens & Yak, Nak \\
\hline 96. & Yak hybrid & Chauri & Yak x cow & Chauri \\
\hline \multicolumn{5}{|c|}{ Aquatic agricultural animal genetic resources } \\
\hline 97. & Apple snail & Ghungi & Bellamya bengalensis & Ghungi \\
\hline 98. & Catla & Bhakur & Catla catla & Bhakur \\
\hline 99. & Chaguni & $\begin{array}{l}\text { Rewa, } \\
\text { Kasree, kubre }\end{array}$ & Chagunius chagunio & Rewa, Kasree, kubre \\
\hline 100. & $\begin{array}{l}\text { Gangetic mud } \\
\text { eel, Cuchia }\end{array}$ & Andho bam & Amphipnus cuchia & Andho bam \\
\hline 101. & Garua bacha & $\begin{array}{l}\text { Jalkapoor, Bai } \\
\text { kha }\end{array}$ & Clupisoma garua & Jalkapoor, Baikha \\
\hline 102. & $\begin{array}{l}\text { Giant Mottled } \\
\text { Eel, } \\
\text { Mottled Eel }\end{array}$ & Raja bam & Anguila bengalensis & Raja bam \\
\hline 103. & Goonch & Gonch & Bagarius yarrellii & Gonch \\
\hline 104. & $\begin{array}{l}\text { Hill trout, } \\
\text { Snow trout }\end{array}$ & $\begin{array}{l}\text { Chuche } \\
\text { Asala, }\end{array}$ & Schizothorax plagiostomus & Chuche Asala, \\
\hline 105. & Kalabans & Gardi & Labeo dero & Gardi \\
\hline 106. & $\begin{array}{l}\text { Katli, } \\
\text { Chocolate } \\
\text { Mahseer, } \\
\text { Copper } \\
\text { mahseer }\end{array}$ & Katle & Neolissochilus hexagonolepis & Katle \\
\hline 107. & $\begin{array}{l}\text { Kuncho River } \\
\text { prawn }\end{array}$ & $\begin{array}{l}\text { Guraicha or } \\
\text { kunchochingri }\end{array}$ & Macrobrachium lamarrei & $\begin{array}{l}\text { Jhinge machha, Sano jhinge, Thulo } \\
\text { jhinge }\end{array}$ \\
\hline 108. & Mahseer & Falame sahar & Tor tor & Falame sahar \\
\hline 109. & Mrigal & Naini & Cirrhinus mrigala & Naini \\
\hline 110. & Mussel & Situ (Seepi) & Lamellidens marginalis & Situ (Seepi) \\
\hline 111. & $\begin{array}{l}\text { Putitor } \\
\text { mahseer, } \\
\text { Golden } \\
\text { mahseer, } \\
\text { thick-lipped } \\
\text { Mahseer, }\end{array}$ & $\begin{array}{l}\text { Sahar, } \\
\text { Mahseer, } \\
\text { Pahele } \\
\text { mahseer, }\end{array}$ & Tor putitora & $\begin{array}{l}\text { Sahar, Mahseer, } \\
\text { Pahele mahseer, }\end{array}$ \\
\hline 112. & Rohu & Rohu & Labeo rohita & Rohu \\
\hline 113. & $\begin{array}{l}\text { Spotted snow } \\
\text { trout, } \\
\text { Alwan Snow } \\
\text { trout }\end{array}$ & $\begin{array}{l}\text { Buchhe } \\
\text { asala, } \\
\text { Blunt snout } \\
\text { asala, } \\
\text { Soal asala }\end{array}$ & Schizothorax richardsonii & $\begin{array}{l}\text { Buchhe asala, } \\
\text { Blunt snout asala, } \\
\text { Soal asala }\end{array}$ \\
\hline 114. & Walking & Mungri & Clarias batrachus & Mungri \\
\hline
\end{tabular}




\begin{tabular}{|c|c|c|c|c|}
\hline SN & & Nepali name & Scientific name & Most important landraces \\
\hline & $\begin{array}{l}\text { catfish; } \\
\text { Magur }\end{array}$ & & & \\
\hline 115. & $\begin{array}{l}\text { Wallago, } \\
\text { Freshwater } \\
\text { shark }\end{array}$ & Padni/ bohari & Wallago attu & Padni/ bohari \\
\hline 116. & Zebra fish & $\begin{array}{l}\text { Chithari, } \\
\text { pothi }\end{array}$ & Danio rerio & Chithari, pothi \\
\hline \multicolumn{5}{|c|}{ Aquatic agricultural plant genetic resources } \\
\hline 117. & $\begin{array}{l}\text { Deep water } \\
\text { rice }\end{array}$ & Bhaati Dhaan & Oryza sativa L. & Bhaati Dhaan \\
\hline 118. & $\begin{array}{l}\text { Gorgon nut, } \\
\text { Prickly water } \\
\text { Lily, Fox nut }\end{array}$ & $\begin{array}{l}\text { Makhan, } \\
\text { Makhana }\end{array}$ & Euryale ferox Salisb. & Makhan, Makhana \\
\hline 119. & Lotus & Komal & Nelumbo nucifera Gaertn & Komal \\
\hline 120. & Taro & Karkale & Colocasia esculenta (L.) Schott. & Karkale \\
\hline 121. & $\begin{array}{l}\text { Toothed dock, } \\
\text { Aegean dock }\end{array}$ & Ban Palungo & Rumex dentatus L. & Ban Palungo \\
\hline 122. & Water chestnut & $\begin{array}{l}\text { Singhara, } \\
\text { Singada }\end{array}$ & Trapa bispinosa Roxb & Singhara, Singada \\
\hline 123. & Water spinach & Karmi Saag & Ipomoea aquatica Forssk. & Karmi Saag \\
\hline 124. & Watercress & Sim Saag & $\begin{array}{l}\text { Nasturtium microphyllum } \\
\text { (Boenn.) Rchb. }\end{array}$ & Sim Saag \\
\hline \multicolumn{5}{|c|}{ Insect genetic resources } \\
\hline 125. & $\begin{array}{l}\text { Asiatic hive } \\
\text { bees }\end{array}$ & $\begin{array}{l}\text { Yasian } \\
\text { mahuri }\end{array}$ & $\begin{array}{l}\text { Apis cerana Fab. } \\
\text { (Ecotypes - Apis cerana cerana, } \\
\text { Apis cerana indica, Apis cerana } \\
\text { himalaya) }\end{array}$ & Yasian mahuri \\
\hline 126. & Bumble bees & Bhamara & Bombus spp. & Bhamara \\
\hline 127. & Cotesia & Bareule kira & $\begin{array}{l}\text { Cotesia flavipes Cameron } \\
\text { (=Apanteles flavipes Szepligeti) }\end{array}$ & Bareule kira \\
\hline 128. & $\begin{array}{l}\text { Green lace } \\
\text { wing }\end{array}$ & $\begin{array}{l}\text { Jalidar } \\
\text { pakeheta } \\
\text { bhayeko kira }\end{array}$ & Chrysoperla carnea Stephens & Jalidar pakeheta bhayeko kira \\
\hline 129. & $\begin{array}{l}\text { Himalayan } \\
\text { giant honey } \\
\text { bee }\end{array}$ & $\begin{array}{l}\text { Jangali } \\
\text { mahuri }\end{array}$ & Apis dorsata Fabricius & Jangali mahuri \\
\hline 130. & Lac insets & Laha kira & Kerria lacca (Kerr) & Laha kira \\
\hline 131. & $\begin{array}{l}\text { Ladybird } \\
\text { beetle }\end{array}$ & $\begin{array}{l}\text { Stri } \\
\text { swabhabko } \\
\text { khapate }\end{array}$ & Coccinella spp. & Stri swabhabko khapate \\
\hline 132. & Leptobatopsis & Bareule kira & Leptobatopsis indica (Cameron) & Bareule kira \\
\hline 133. & Little/small bee & Sano mahuri & Apis florea Fabricius & Sano mahuri \\
\hline 134. & $\begin{array}{l}\text { Rock or cliff } \\
\text { honey bees }\end{array}$ & Bhir mahuri & Apis laboriosa Smith & Bhir mahuri \\
\hline 135. & Stingless bees & $\begin{array}{l}\text { Nachilne } \\
\text { mahuri } \\
\text { (putka) }\end{array}$ & $\begin{array}{l}\text { Mellipona spp. } \\
\text { Trigona spp. }\end{array}$ & Nachilne mahuri (putka) \\
\hline 136. & Tachinid fly & Tyakinid kira & Exorista japonica Townsend & Tyakinid kira \\
\hline 137. & Tamarixia & Bareule kira & Tamarixia radiata (Waterston) & Bareule kira \\
\hline 138. & Telenomus & Bareule kira & Telenomus sp. & Bareule kira \\
\hline 139. & Trichogramma & Bareule kira & Trichogramma chilonis Ishii, & Bareule kira \\
\hline \multicolumn{5}{|c|}{ Microbial genetic resources } \\
\hline 140. & Termitomyces & $\begin{array}{l}\text { Kalo dunge } \\
\text { chayu }\end{array}$ & Termitomyces spp & Kalo dunge chayu \\
\hline 141. & Azotobactor & Azotobactor & Azotobactor spp & Azotobactor \\
\hline 142. & $\begin{array}{l}\text { Black Forest } \\
\text { Mushroom, } \\
\text { Shiitake }\end{array}$ & Mruge Chyau & Lentinula edodes & Mruge Chyau \\
\hline 143. & $\mathrm{Bt}$ & Biti & Bacillus thuringiensis & Biti \\
\hline 144. & $\begin{array}{l}\text { Clustered } \\
\text { coral/ }\end{array}$ & Thakre Chyau & Ramaria botrytis & Thakre Chyau \\
\hline
\end{tabular}




\begin{tabular}{|c|c|c|c|c|}
\hline SN & English name & Nepali name & Scientific name & Most important landraces \\
\hline & $\begin{array}{l}\text { Cauliflower } \\
\text { coral }\end{array}$ & & & \\
\hline 145. & $\begin{array}{l}\text { Green } \\
\text { muscardine } \\
\text { fungus }\end{array}$ & Hariyo dhusi & Metarhizium anisopliae & Hariyo dhusi \\
\hline 146. & $\begin{array}{l}\text { Milky } \\
\text { Mushroom }\end{array}$ & Dudhe Chyau & Calocybe indica & Dudhe Chyau \\
\hline 147. & Morel & $\begin{array}{l}\text { Guchhi } \\
\text { Chyau }\end{array}$ & $\begin{array}{l}\text { Morchella esculenta } \\
\text { Fr. }\end{array}$ & Guchhi Chyau \\
\hline 148. & Puffball & Padke chayu & Clavatia spp & Padke chayu \\
\hline 149. & Rhizobium & Rhizobium & Rhizobium spp & Rhizobium \\
\hline 150. & $\begin{array}{l}\text { Shaggy Ink } \\
\text { Cap/ Shaggy } \\
\text { Mane }\end{array}$ & $\begin{array}{l}\text { Kalo Masi } \\
\text { Chyau }\end{array}$ & Coprinus comatus & Kalo Masi Chyau \\
\hline 151. & $\begin{array}{l}\text { Straw } \\
\text { Mushroom }\end{array}$ & Parale Chyau & Volvariella volvacea & Parale Chyau \\
\hline 152. & $\begin{array}{l}\text { Super } \\
\text { Natural/Red } \\
\text { Mushroom }\end{array}$ & Rato Chyau & Ganoderma spp & Rato Chyau \\
\hline 153. & Trichoderma & Trichoderma & Trichoderma spp & Trichoderma \\
\hline 154. & $\begin{array}{l}\text { White- } \\
\text { muscardine } \\
\text { fungus }\end{array}$ & Seto Dhusi & Beauveria bassiana & Seto Dhusi \\
\hline 155. & Yarsha-gumba & $\begin{array}{l}\text { Yarshaguumb } \\
\text { a }\end{array}$ & Cordyceps sinensis & Yarshaguumba \\
\hline 156. & Yeast & $\begin{array}{l}\text { Dhahi } \\
\text { jimaanu }\end{array}$ & Lactobacillus spp & Dhahi jimaanu \\
\hline 157. & Yeast & $\begin{array}{l}\text { Dhahi } \\
\text { jimaanu }\end{array}$ & Streptococcus & Dhahi jimaanu \\
\hline 158. & Yeast & $\begin{array}{l}\text { Marcha } \\
\text { jimaanu }\end{array}$ & Saccharomyces cerevisiae & Marcha jimaanu \\
\hline
\end{tabular}

Sources: Regmi 1982, Banwart 1989, Paudel and Tiwari 1992, Upadhyay et al 1995, Smith et al 1996, Wilson 1997, Shrestha and Shrestha 1999, Yami et al 2003, Arjyal et al 2004, MoAC 2004, Takeda et al 2004, Christensen et al 2008, Niroula and Sing 2011, Acharya and Atreaya 2012, Gotame et al 2014, Aryal et al 2015, Bhattarai et al 2015, Shimada and Basnet 2015, Paudel 2017, Subba et al 2017, Wilson 2017, Limbu et al 2019, FAO 2019.

||------||-------|| 